The arl Beck Papers in Russian \&

East European Studies

Number 1603

Marcello Cherchi and

H. Paul Manning

\section{Disciplines and Nations: \\ Niko Marr vs. His \\ Georgian Students \\ on Tbilisi State University \\ and the Japhetidology/ \\ Caucasology Schism}


Marcello Cherchi earned a Ph.D. in linguistics from the University of Chicago in 1996. He has published three books and fifteen articles on topics in morphsyntax, grammaticization, analogical formation, phonology, language contact, literature, ethnography, linguistic historiography, Georgian grammar and the neuroanatomical substrates of language processing.

H. Paul Manning earned a Ph.D. in linguistics from the University of Chicago in 2001. He has taught most recently at Bard College, and is currently involved in a multi-year project on the emergence of the Georgian intelligentsia and the notion of "Georgianness," funded by the NEH and NCEEER.

No. 1603, September 2002

(C) 2002 by The Center for Russian and East European Studies, a program of the University Center for International Studies, University of Pittsburgh

ISSN 0889-275X

The Carl Beck Papers

Editors: William Chase, Bob Donnorummo, Ronald H. Linden

Managing Editor: Eileen O'Malley

Editorial Assistan: Zsofia McMullin

Cover Design: Mark Weixel

Submissions to The Carl Beck Papers are welcome. Manuscripts must be in English, double-spaced throughout, and between 40 and 100 pages in length. Acceptance is based on anonymous review. Mail submissions to: Editor, The Carl Beck Papers, Center for Russian and East European Studies, 4G-17 Posvar Hall, University of Pittsburgh, Pittsburgh, PA 15260. 
It is arguable that no figure in Soviet linguistics has had more influence on that and related disciplines than the Georgian linguist Nikolaj Jakovlevich Marr (in Georgian, Niko Iakobisdze Mari) (1864-1934). This influence was so powerful and pervasive that its end was stipulated by no less a figure than Joseph Stalin, in no less a venue than a "debate on linguistics" held on the pages of Pravda in 1950. Marr's role in the development of Soviet linguistics, ethnology, and other disciplines has been the focus of numerous other works, and in this essay we will confine our attention primarily to the pre-Soviet Marr, attending to a series of often acrimonious disputes between Marr and his Georgian colleagues and students that marked the transition of his intellectual and political interests from a parochial focus on Georgia and the Caucasus to a far wider purview. In this transition, Marr's increasingly antagonistic relationship with his Georgian students, coming to a head with the founding of Tbilisi State University in 1918, plays a major role. We believe that the seeds of many crucial changes in Marr's theories were sown in this period, and our objective is to place Marr in his Georgian context.

The essay will examine Marr and the impact of his work from several perspectives. After some biographical information and a brief introduction, the first main section ("Changes in Marr's Views") attempts to demonstrate that from the methodological viewpoint, some of his early work was actually well within the paradigm of comparative linguistics at the time. In the second section ("Marrism and Marxism") we shall examine in fairly general terms the relationship between these schools of thought. In the third section ("Marr's Dialogue with the Georgians: Identities and Differences") we investigate in detail a number of Marr's personal relationships - virtually all antagonistic - which seem to have been significant in his career. This includes how Marr and Ivane Dzhavakhishvili had different reactions to the discipline of Indo-European comparativist linguistics (and its perceived sociohistorical and colonialist implications) prevalent in Europe at the time; how Marr's view of the position of the Kartvelian languages and dialects (and of their speakers) differed from that of many scholars, particularly, Akaki Shanidze, who later became the most widely known Georgian grammarian; and finally how Marr's ideas concerning the purpose and structure of the proposed university in Tbilisi ultimately were not accepted by his own students. The fifth section ("Marr's Reactions to the Georgian University") attempts to gain some perspective on how Marr reacted when Tbilisi State University was founded - contrary to his wishes - by the very students who, in his view, had abandoned him. 
Over a century ago Niko Marr began to develop what came to be known as the "Japhetic" theory, essentially a sociocultural hypothesis regarding language origins, development, and relatedness. He remains a figure of central historical interest, both from the ambiguous legacy of his impact on Soviet linguistics and social sciences and for his less well-understood impact on the study of the Caucasus. However, the understanding which many (particularly Western) scholars have of Marr's influence frequently derives primarily, if not exclusively, from the official debunking of his theories in the 1950 discussion in Pravda; and more detailed Western accounts of Marrism (Thomas 1957a, b; Samuelian 1981; Clark 1995; Slezkine 1996) have viewed Marr primarily from a Pan-Soviet perspective, with the result that his early relations with his Georgian students have been neglected. In recent years there has been renewed interest in the West concerning Marr's manifold impact on diverse domains of Soviet scholarship and society (for example Samuelian 1981, Smith 1991, Clark 1995, Slezkine 1996 and references there), yet there has been very little investigation of Marr's relations with his first generation of Georgian students. We intend to show that a schism between Marr and the Georgians provides a significant missing link in the development of Japhetidology.

We propose to examine the portion of Marr's career before, during, and soon after the founding of Tbilisi State University in 1918, paying close attention to an evolving dialogue between Marr and his students. We suggest that the founding of the university and the institutionalizing of separate fields of Caucasology and Kartvelology effectively deprived Japhetidology not only of its first crop of students, but also of its "Caucasian base": in this period, Japhetidology would undergo a number of changes in theory, method, and scope as a result.

Our problem revolves around a number of hitherto unexplained facts in the fortunes of Japhetidology: (1) During the period from 1917 to 1924, Japhetidology's purview underwent its greatest territorial expansion, moving beyond its Caucasian base to the point that Marr's erstwhile colleague Dzhavakhishvili complained in 1928 that it seemed "on the verge of owning all the peoples on earth" (cited in Charachidze 1959: 71). (2) This quantitative transition was followed by a number of qualitative changes in the theory, the most important for our purposes being Marr's methodological move against what he termed "Caucasocentrism" in his theory by 1922. (3) Finally, to date there has been no adequate explanation as to why Arnold Chikobava, a Georgian Caucasologist, was chosen by Stalin to deliver the coup de grâce to Marrism in the Pravda discussion in 1950 (Chikobava 1950, 1985). 
The period from 1916 to about 1922 therefore becomes a period of crucial importance. While many of the more intriguing changes in Marr's theory, such as the rapprochement with Marxism, occurred even later, for Marr as well as for students of Marrism, the crucial turning point occurred during this period (Shnirelman 1995: 122). Soon thereafter, to this change from a Caucasocentric theory to a non-Caucasocentric one was added a change in name from "Japhetidology" to the "New Theory of Language" (Clark 1995: 212).

We will argue that Marr's move into new disciplines from around 1917 and the change in his theory in 1922 are related to the mutual distancing between Marr and his former students and colleagues over the founding of Tbilisi State University (announced in 1917), and a resulting schism between Marr's own Japhetidology and the new disciplines of Caucasology and Kartvelology. Furthermore, the establishment of these disciplines in Tbilisi effectively produced an institutional hotbed of resistance to Marrism in Georgia which eventually yielded the logical candidate for a hatchet man (Chikobava) to open the discussion on Marrism in 1950. By considering Marr's work and career from this perspective, we hope to glean insights that are different from (and complementary to) those obtained by following only the Soviet aspect of Marr's career up to 1950 .

\section{Changes in Marr's Views}

Viewing Marr's career retrospectively from 1950 (Murra et al. 1951) tends to cast his work as a monolithic unity. However, the fact that many scholars (Thomas 1957a: 332, Charachidze 1959: 71) -including some of his staunchest critics (Shanidze 1920b: 5, Chikobava 1950: 19, Dzhavakhishvili 1937: 9-11, 77) — acknowledge the great philological value of Marr's early work (particularly on Armenian and Georgian) while disputing his later work, is an indication that Marr's output is not homogeneous and that his thinking changed. It is for this reason that several scholars have emphasized the importance of examining the development of his ideas (Thomas 1957a: 324-25). Of particular concern in this section is his stance with respect to Indo-European comparativism. While Marr strongly opposed the Eurocentrism of the comparativists throughout his career, initially his analytical techniques and categories were at least recognizable parallels to the comparativist methodology. We wish simply to establish that initially Marr's work was not drastically different, at least in intent, from that of the comparativists. Since many of Marr's first generation of students were later to break with him precisely on the basis of his methodology, it is crucial to demonstrate that in this earlier period they might have felt able to work with him on topics in Kartvelology and Caucasology under the rubric of Japhetidology. 


\section{Before the schism: Marr as a Comparativist}

Marr (1888) posited a genetic relationship between Georgian and Semitic, without, however, providing any details. It was not until 1908 that he substantiated this claim with actual data.

Marr (1908: 10) mentions three basic reasons for positing this relationship, all of which we might call broadly typological (although he does not use that term himself). The first, from the domain of phonetics, is that "Georgian, displaying, similarly to Semitic, an overwhelming example of preeminent development [preimushchestvennogo razvitija] of consonants, shares with them [i.e., with Semitic languages] a richness and diversity of guttural sounds." The second reason, from the domain of morphology, consists of two parts: (a) Georgian, like Semitic, uses vowels (intercalated in various patterns between consonants) to convey etymological categories (ètimologicheskie kategorii), by which he probably means to refer to the distinctive Semitic verb patterns (Hebrew binynîm, Arabic "Forms I-XV") and noun patterns (Hebrew sheqālîm), and putatively similar morphological phenomena in Georgian; (b) both Georgian and Semitic use suffixes and prefixes. The third reason, concerning the lexicon, is that in both Georgian and Semitic, the basic lexical meaning is carried by a consonantal root (generally triconsonantal, though occasionally biconsonantal).

In addition to these broad similarities, Marr offers seven specific ones. First, he alludes (1908: 11) to certain syntactic similarities without specifying which ones. He may be referring to a later section of the paper (26) in which he discusses how, although Georgian exhibits determiner-determined word order (e.g., adjective-noun), certain constructions (kinship terms and certain compounds) preserve what seems to be an older word order of determined-determiner (e.g., mama-chemi lit. 'father-mine', i.e., 'my father'). Second, he claims (11) that Georgian has "only three basic cases, as in Arabic," and that, furthermore, Georgian's three basic cases are vocalic, viz., NOMINATIVE $-i$ (which he claims is from * $-u$ ), GENITIVE $-i$, and DATIVE/ACCUSATIVE $-a$, and that they therefore resemble the three cases of Arabic (NOMINATIVE - $u$, GENITIVE $-i$, ACCUSATIVE $-a$ ). Third, he claims (12) that the final consonants of certain Georgian cases have parallels in Semitic, specifically: Georgian $-s$ parallels Hebrew $-h$. Fourth, he relates Georgian's nariani plural formation (viz., plural marker $-n$ in the NOMINATIVE and VocATIVE) to Arabic nunation. Fifth, he notes (12) that Georgian can form past passive participles with two different vowels (viz., Georgian dac 'erili 'written', gak'etebuli 'done'), and that Semitic does the same (viz., Arabic maf' $\bar{u} l$ '[that which has been] done', qatil ' [he who has been] killed'). Sixth, he notes (12) that Georgian's (active) participles are formed with the prefix $m(V)$-, similarly to Semitic. Although he provides no data, he probably has in mind forms such as 
Georgian $\underline{m a}$-sc 'avlebeli 'teacher', Hebrew $\underline{m}^{e}$-lammēe 'teacher'. Seventh and finally, he (11) claims to have identified "about a thousand" lexemes shared by Georgian and Semitic.

Marr (1908: 19-26) lists twenty "cognate sets" intended to demonstrate the "correspondence" of Semitic/h, h, ", "/ with Japhetic/s/. These cognate sets, coupled with the broader language similarities mentioned earlier, make it fairly clear that he was thinking in terms of genetic relatedness familiar to historical linguistics even today. Indeed, it should come as no surprise that he begins the article by stating that "the Georgian language turns out to be a characteristic representative of a particular linguistic branch which, in its turn, stands in a genetic relation with the Semitic branch of languages" (8, emphasis added), nor that he describes them as "standing in relationships of cousins" whose parents, proto-Semitic and proto-Japhetic, are siblings (24). Any doubt that he was thinking in these terms is removed when one considers figure 1 (adapted and translated from Marr's [1910: xxiii] grammar of Laz). xxiii) $)^{1}$

Figure 1. Genealogy of the Japhetic Languages (adapted from Marr 1910:

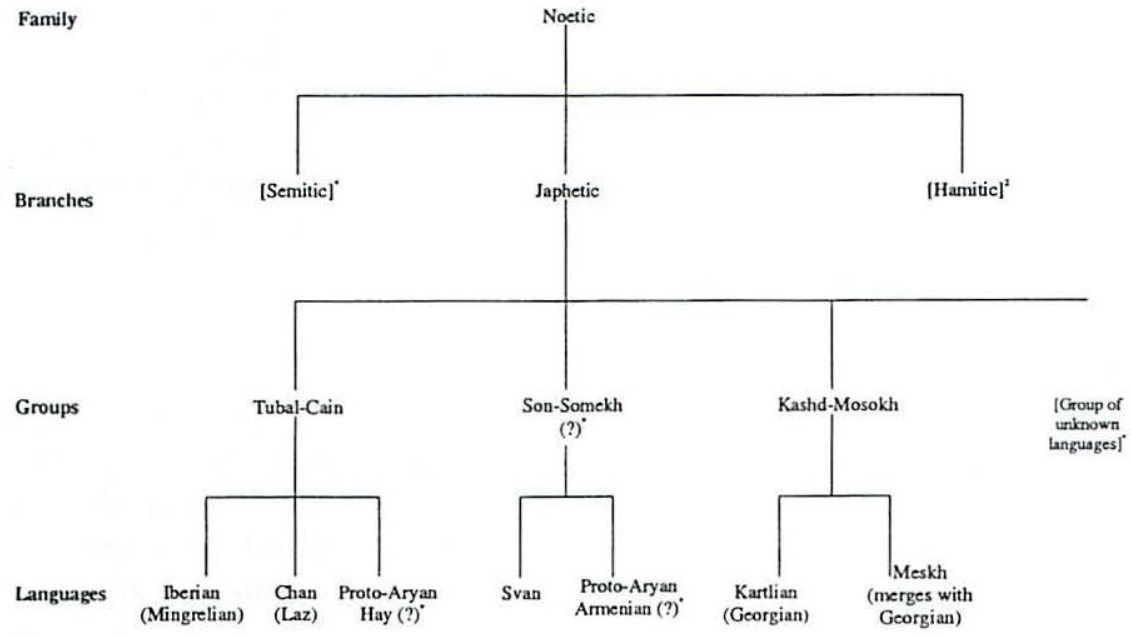

1. The languages are given with Marr's exact notation as presented in Marr's work e.g., the bracketed forms such as "[Semitic]" and the question marks are reproducced from his table and are not modifications by the present authors.

2. Marr gives the label "Hamitic" to Indo-European, though the notion obviously does not match the scholarly opinion prevalent at the time. 
Given the various aspects of Marr's approach (at least up to 1910) discussed in this section, it should come as no surprise that Matthews (1949: 175) says the following of Marr up until the 1920s: "At that time . . . Marr still accepted the prevailing Indo-European doctrine of the linguistic archetype (protoglossa, Ursprache)." Similarly, Ellis and Davies (1951:211) say of Marr that "till 1924 . . . his work was carried out within the framework of the orthodox method, but he used this method on almost entirely untouched material." While this latter analysis is surely factually incorrect (Thomas 1957b), it is revealing inasmuch as Marr's theories up to that point were at least susceptible of being mistaken for linguistics as usual. While it is surely an overstatement to divide his career neatly into "orthodox" and "heterodox" periods (Thomas 1957a, b), it is clear that Marr, however defective his application or understanding of comparativism might have been, nevertheless made some attempts to make use of it at an early stage, "yet gradually he became ever more intransigent against Indo-Europeanism given his poor reception both in the West and at home" (Smith 1991: 75). During the early part of his career, his methods of linguistic analysis appeared to be in line with the school of Indo-European comparativism in at least a few important respects. In terms of purview, if not method, what Marr seemed to be proposing around 1910 was in effect the same as Kartvelology, and anywhere from 1911 to 1916 was in effect Caucasology (Thomas 1957b: 39). When his students left St. Petersburg in 1917, he was still practicing a theory that had at least some commonalities with those they hoped to transfer to the Caucasus. Indeed, the recent attempts by Georgian scholars to rehabilitate Marr (Dzidziguri 1985, 1988) have focused on his work from this period, most of which readily falls within now established disciplinary boundaries and projects such as Rustavelology, Kartvelology, and Caucasology.

\section{After the Schism}

The ways in which Marr's thought later in his career diverged from and became strongly opposed to that of the Indo-European comparativists have been sufficiently documented elsewhere; we need only summarize some of the major points of difference after the period in which we are interested, with the caveat that Marr is a "moving target," constantly changing his positions and altering his theories (Ellis and Davies 1951: 215; Rubenstein 1951: 282). In fact, the constant reformulation of his ideas (frequently contradicting immediately prior statements) was one of the points that his critics held against him (e.g., Dzhavakhishvili 1937: passim). Infamous among Marr's "mature period" inventory of tools for language study was his "four-element analysis," also known as "linguistic paleontology" (Manning 1931: 144; Dzhavakhishvili 1937: 71; Matthews 1949: 
174; Matthews 1950: 14; Chikobava 1950:1; Ellis and Davies 1951: 213; Rubenstein 1951: 283; Thomas 1957a: 327). According to this method, all existing lexical material in all languages derives ultimately from four elements (whose original forms were sal, ber, yon, rosh) which could undergo practically unlimited phonetic changes. This method "permitted indulgence in the wildest and most absurd etymologies" (Matthews 1950: 14). While in principle the method could be applied to any words, Marr tended to examine very limited spheres of vocabulary such as "ethnic terms, toponymic designations, and eponyms" (Thomas 1957a: 327). As Thomas has noted, this methodological privileging of a small portion of the vocabulary is an outgrowth of his "Caucasian period," and he "was later to canonize this procedural technique into his famous 'four element analysis' (quietly suppressing, at the same time, all references to its origin)"(327).

The four units of paleontological analysis were supposed to be primordial elements of primitive human speech and thus were closely tied to Marr's conception of language origins which, early in his career, could be classified as "monogenetic" (Rubenstein 1951: 282). At a certain point he maintained that in the "glottogonic" (Ellis and Davies 1951: 216) or "glossogenic" process (Matthews 1950: 16) all languages have the same starting point and follow the same path of development; the reason languages differ from each other is that they develop at different rates (Manning 1931: 145; Ellis and Davies 1951: 216; Rubenstein 1951: 282, 284).

As languages proceed along this path of development they are supposed to pass through various discrete stages. In this "stadial" construct of Japhetic theory there is supposed to be a correspondence between the morphological development 1 of a given language and the level of economic development 2 of the society in which it is spoken (Matthews 1950: 15; Ellis and Davies 1951: 216; Rubenstein 1951: 282-83). Related to the stadial construct was the idea of "layers," namely, that a single language could contain various layers from different social strata and thus from different stages of development (Thomas 1957a: 32729).

With the construct of stadialism in place, Marr eventually came to conceive of Japhetic as a stage through which other languages pass in the course of their development (Ellis and Davies 1951: 217; Rubenstein 1951: 282; Thomas 1957a: $331,329-30$ ). This constitutes a significant break from his earlier thinking. Earlier he had considered Japhetic to be a "cousin" of Indo-European; but later he thought both Indo-European and Semitic to be later developments from Japhetic languages (Dzhavakhishvili 1937: 72). 
At least one scholar claims that at this point "Marr was using these devices [the theory of stages and layers] to establish a genetic affiliation" (Thomas 1957a: 329, emphasis in the original). In fact, as late as 1926 he even depicted the (typological-genetic) relation of languages in a vaguely arboreal-formatted diagram (Marr 1926b: 314). However, he ultimately "abandoned [the genealogical tree] in 1928, because the branches spreading from the trunk suggested too vividly the theory of the protoglossa, which it was his avowed purpose to confute" (Matthews 1949: 188). By this time Marr no longer accepted the construct of a proto-language (Rubenstein 1951: 283). This also meant that he had ceased to think in terms of genetic relationships. Therefore he began speaking of a Japhetic "system" rather than a Japhetic "family" (Matthews 1949: 182). At this point, "linguistic relationship is conceived no longer as biological and genetic, but as the historical and sociological integration of a multitude of diverse ethnic languages" (Matthews 1949: 185).

In this section we have sought to show that in the later part of Marr's career his ideas and methods were recognizable as being thoroughly opposed to those of the Indo-European comparativists. Before concluding, we should note that despite all the characteristics of Marr's theories that set him against the comparativists, Thomas maintains: "Nor is Marr to be taken as one who objected to the principles of Indo-European comparativism. . . He objected to comparativism not on principle, but simply because it did not serve those transcendental aims which were dear to him" (1957a: 331, emphasis in the original). Among these aims were to "link ... his isolated mother language to one of the great cultural linguistic families" (325) and more generally to assign the Japhites, and "above all . . . the Caucasian Japhites" (331) a central role in its "participat[ion] in the creative remodeling of European world-culture" (Matthews 1949: 182; also Slezkine 1996).

\section{Marrism and Marxism}

Marr presents himself to latter-day scholars as a curiously ambivalent character: his ideological critiques are often quite cogent and indeed prescient, yet his empirical exemplifications and theoretical justifications often seem the product of febrile imaginings (Marcellesi 1977, Yaguello 1984.) Moreover, he simply fails to put his own ideology into practice. While he lambastes IndoEuropeanists for neglecting living languages, focusing on the past, and preferring theory to practice, these are errors which he himself commits, to the extent that Smith (1991) speaks of Japhetidology as a "program for ideology" as opposed to, for example, the Jazykfront "program for action" (see also Thomas 1957a: 335-38). Moreover, his practical implementation, or empirical exemplification, 
of this ideology is often frankly bizarre, leading to a temptation to rehabilitate or condemn him on the basis of a partial consideration of his views. Western receptions of Marr are equally contradictory, valuable more as a barometer of the Western intellectual climate than anything else: some have attempted to rehabilitate him as a failed first effort at a critical sociolinguistics (Marcellesi 1977), or as a critique of the colonialist ideology latent in European linguistics (Calvet 1974); others have seen a political ideologue whose attempts to politicize science are "unpardonable" (Meillet 1928); and still others have viewed Marr as, quite simply, a "lunatic" but, unfortunately, "not sufficiently insane to put into an institution" (Trubetzkoy 1924: 317). Samuelian gives the following measured appreciation of Marr's Janus-like duality:

As for the concrete linguistic work itself, while it may be intriguing to unravel the intricate web Marr spun out of the languages he saved from isolation in order to capture and cushion the beliefs he for one reason or another held dear, the beliefs themselves should not be so readily dismissed. When considering the web, one recalls Marr's horror stories of the "ready-made, imported sound laws" the Indo-Europeanists employed, and wants to say de te fabula narratur. When considering the beliefs themselves, one has to pause, in the light of recent developments in socio- and ethno-linguistics to appreciate how enlightening such perspectives on language could be if executed with measure and skill. (Samuelian 1981: 184-85, emphasis in the original)

Both positive and negative receptions of Marr's theories in the West have generally tended until recently toward a radical homogenization of his views to a list of a few basic features, depending on whether he is to be debunked or rehabilitated. If the former, the list almost always contains the infamous fourelement analysis characteristic of his "mature phase"; if the latter, the list contains only those of his views that can be considered a nascent attempt to reformulate linguistics on the basis of Marxism, specifically the view of language as a superstructure, and the theory of "class languages." In this latter assessment, which follows in broad outlines the critiques of Marrism in the 1950 Pravda discussion, the Marxist elements of late Marrism come to be substituted for Marrism as a whole. Conversely, Marxist linguists in the West, especially French Althusserian Marxists (see Baggioni 1977) have tended to treat Marrism as the only Soviet contribution to Marxist linguistics between Lafargue and the present, ignoring the manifold concurrent attempts in the early Soviet period to reformulate linguistics on a Marxian basis, among them the contributions of Jazykfront, Polivanov, Voloshinov (himself clearly directly influenced by Marr; see Smith 1991), and others (see Samuelian 1981, Smith 1991 and references there). 
This tradition of "vulgar Marrism" (e.g., Marcellesi 1977: 22), if we may call it that, produces a teleological reading of Marr, such that those early elements of Japhetic theory that later came to be identified with corresponding Marxist elements (what Samuelian 1981 calls "doublets") are read only with the latter interpretation in mind, and the historical development of Marr's views is elided.

Most investigators seem to agree that at some points in Marr's career his linguistic theory exhibited various elements reminiscent of one or another variety of Marxism, for instance, his contention that Indo-European was an "in-situ transformation" of Japhetic spurred on by the economic phenomenon of metallurgy. This was liable to be interpreted by Marxists as an example of language being a "superstructure" on an (economic) "base," and although initially Marr did not cast it in explicitly Marxist parlance, it has been viewed as a "first step" in that direction (Ellis and Davies 1951: 212-13). Eventually this was generalized as a causal relationship between economic stages and linguistic stages, involving "changes from one stage to another by sudden 'dialectal' leaps ... on the basis of Thomas (1957a: 335-38) considering language a superstructure like law, philosophy and art, which consequently, like them, changes suddenly with each sudden change in the economic basis" (Ellis and Davies 1951: 217). Other apparently Marxist elements include the theory of "stages" (casting language as a class phenomenon) and the theory of "layers" (according to which a single language could contain layers from different social strata).

Up to 1925 Marr was producing in the New Theory of Language "doublets of Marxist themes," such as those just listed, which were taken, beginning in 1925 with Lunacharskij, as "independent proof of the 'truth' of Marxism" (Samuelian 1981: 271-72). From the late twenties on, Marr made these connections explicit: "Marr progressed to a Marxian ideology, using it to batten his older Japhetidological theories with a new framework" (Smith 1991: 164). However, there is disagreement about when Marr began invoking Marxism and the extent to which his attempted rapprochement with Marxism was a central causal force in the change from Japhetidology to the New Theory of Language.

Some investigators assert that Marr and his theories were fundamentally Marxist (Manning 1931: 146, Rubenstein 1951: 282); however, many avowedly Marxist scholars both inside and outside Russia were quite skeptical of his Marxism, some completely denying it long before the official debunking in 1950 (Matthews 1950: 21; Chikobava 1950: 9, 10; Thomas 1957a: 333; Charachidze 1959: 72). Thomas (1957a: 333) casts doubt on the thoroughness of Marr's Marxism by observing that "in the early 1920's there were very few elements in Marr's theories that could be called Marxist," and that "it was not until 1928 that Marr began publishing works containing a rather more extensive attempt to graft 
Marxism to his theory" (338). Moreover, it is significant that a few Marxist-like elements of Marr's theories actually existed well before 1917 and therefore could not have been triggered by the Marxist milieu of and after the Revolution (328). They were equally unlikely to have been due to emergent Marxist ideas prior to 1917 since "Marr knew no Marxism before the Revolution" (333).3 Thomas instead suggests that "Marr's theories developed largely by virtue of their own internal dynamism" and that any Marxist doublets are the "result of an adaptation to Marxism and not a conscious theoretical construct on a Marxist basis" ( 331 , emphasis in the original) .

The crucial questions for our purposes are When did Marr's theories come to be self-consciously directed toward Marxism? and Can the changes we see in Marr's theories from 1917 to 1924 be attributed to this set of influences? Samuelian (1981), following Thomas' assessment that the New Theory of Language (circa 1924) was a product of earlier lines of development, proposes that Marr was in effect unwittingly producing doublets of Marxist themes until at least 1925, whereupon he became increasingly aware that his "spontaneous" Marxism was in effect an advantage over more self-conscious forms of Marxist linguistics (such as that of Jazykfront, for example):

Marr's theory until the very end of the decade when he began using Marxist symbols, was a doublet or so he would have his contemporaries believe and indeed it appears to have been. The seeds of the New Theory were sown in the pre-revolutionary period, when it is argued that Marr could not have been well enough acquainted with Marxism to reconstruct linguistics on a Marxist foundation. ... In any case, being a doublet was something of an advantage since his theory could be taken as independent proof of Marxism-an angle which was exploited. (Samuelian 1981: 292-93)

In fact, according to Samuelian, the 1927 Baku course on the New Theory of Language is "the first time [Marr] explicitly used Marxist symbols, placing language in the superstructure" (1981: 286). The earlier doublets of Marxism came to be explicit identifications around this point, perhaps fueling the temptation to date Marr's conversion to Marxism back to the time of the Revolution. However, the transitions that brought these doublets of Marxism into existence cannot be due to conscious imitation of Marxism, since, as Samuelian notes, the seeds of this transition were planted in the pre-Revolutionary period. Indeed, the change from Japhetidology to the New Theory of Language was first announced in 1923 (Thomas 1957b: 72, Samuelian 1981: 266), before 
any clear indications of Marxism in Marrism. In what follows, we will attempt to show that the pre-Revolutionary seeds that gave rise to the New Theory of Language germinated in the revolutionary period, and Marr's dialogue with the Georgians, culminating in the founding of Tbilisi State University, played a central role in this process.

\section{Marr's Dialogue with the Georgians: Identities and Differences}

We do not intend to construe Marr's thought as neatly divisible into an earlier "procomparativist" phase and a later "anticomparativist" phase. In fact, his theories changed frequently and dramatically during his career. Given the prolific, varied, and complex nature of Marr's work, it is important to emphasize that the changes are unlikely to be due to any single cause. Existing scholarship has adequately covered the many forces at play in the development of Japhetic theory: purely reactive ones-the reaction against Indo-Europeanism, the Jazykfront incident, Polivanov's criticisms (e.g., Thomas 1957a, b; Samuelian 1981; Smith 1991, Slezkine 1996); assimilative ones - the rapprochement with Marxism (e.g., Samuelian 1981; Smith 1991); immanent ones-the working out of internal methodological and theoretical contradictions (Thomas 1957a, b); as well as telic ones-Marr's manifest desire to unite, rather than divide, all the orphaned peoples of the world to his own (Thomas 1957a, b; Slezkine 1996); and even personal ones (Clark 1995). Instead of focusing on these factors, we will examine the relation of Marr to his Georgian students and colleagues on five central issues over which they came ultimately to part company, even if, as is the case with some, their initial positions had been very close.

We shall avoid simply "debunking" Marr or attempting only to rehabilitate him. We make a special effort to show, given that the positions of his opponents are widely held to be "natural" and "obvious," how these opinions might not have been so, and indeed, might be no less eccentric than Marr's if held up to scrutiny. We make no special claim to objectivity: the issues involved are important, if only because they have had serious social consequences, and still do. When dealing with a figure as simultaneously influential and frankly bizarre as Marr, it is difficult to avoid casting his critics in the role of heroes or "scientists" and Marr as the villain or "crackpot." His own subjugation of reason to rhetoric was so explicit that it is sometimes difficult to see his opponents as anything but paragons of rationalism. However, Marr was at his best and most cogent when pointing out the ideological underpinnings and consequences of his opponents' theories, hence we must also "ideologize" the positions of his opponents, which have come to be seen, in retrospect, as being "natural," "objective," and "obvious": 
"Showing the earlier positionality of a regime of representation that now seems simply a matter of 'letting nature speak for itself' is especially important when, as often happens, the establishment of a natural phenomenon is not only warrant for a scholarly discipline, but is also called on to legitimate and authorize political programs" (Gal and Woolard 1995: 132-33).

The development of Marr's views can be seen in terms of a "dialogue" with various Georgians (students, colleagues, authors, and others) comprising three major phases. During the first phase, he was united with certain of his Georgian students as "antithesis" or "response" to some preexisting "thesis" or "statement." (1) Marr's negative assessment of the theoretical, empirical, and political aspects of Indo-European comparativism was shared with his first student and close colleague Ivane Dzhavakhishvili, founder of Tbilisi State University (T.S.U.) and dean of the department of Georgian history. Indeed, they were fellow travelers on the issue as early as 1902 . However, we will show that while they had identified a common problem and clearly had discussed the matter, they differed in their proposed solutions. (2) Similarly, both Marr and Dzhavakhishvili, as a younger generation of foreign-educated "sons," found themselves standing united as a "scientific" opposition to the "advocative" patriotism of an older generation of Georgian intelligentsia. The issues in dispute concerned foreign influences on Georgian literature, in particular the question of an alleged Persian story that was the material for Shota Rustaveli's poetic monument, the Vepxist 'q'aosani (The knight in the tiger's skin). Unfortunately, space limitations prevent us from giving a full discussion of this stage of the debate. At this point in the developing dialogue, Marr shares with the other Georgians a position of response, and while their specific responses differed, these differences were minimal compared to their differences from the "thesis" they opposed. However, in both these phases the germs of difference and therefore disagreement were present; in each case Marr would make the more radical response, usually proposing some sort of complete "revolutionary" inversion of conventional wisdom, while his Georgian colleagues would advocate a more cautious and conventionally scientific "reformism."

In the second phase of the dialogue we find the Georgians standing opposed to Marr. (3) Marr's moves to include more and more languages into his burgeoning family, eventually extending beyond the Caucasus and beyond the accepted shortlist of orphaned languages of Eurasia, threatened to reduce the Caucasian languages, and Georgian in particular, to the status of methodological ground against which new items would be compared, rather than the discrete and integral objects of the discipline of Caucasology. Dzhavakhishvili, founder of Caucasology, felt that Marr's project showed signs of moving into a discipline 
that had no boundaries at all. Just as Marr tried to unify by assimilation, the Caucasologists sought to unify the Caucasus by definition (and exclusion). Their methodological emphasis would be placed on phenomena that were specific characteristics of Caucasian languages as opposed to non-Caucasian languagesverbal agreement with noun classes (Dzhavakhishvili 1937), ergative construction (Chikobava 1948, 1961) - and Georgian would be shown to have these (ergative construction), or allegedly to have once had them (verbal agreement with noun classes). (4) While the Georgian language with its dialects plays a pivotal role in Japhetidology, as it does in both Caucasology and Kartvelology, in Japhetidology it increasingly becomes a methodological measuring stick of "Japheticness" rather than an empirical object to be studied in its own right. As a result, Georgian increasingly is backgrounded and revealed to contain multiple mixtures and levels. Marr comes to take a highly "impurist" view of the object of the field of Kartvelology (i.e., Georgian), a view which is entirely distinct from the relatively conventional "purist" position of Kartvelologists like Akaki Shanidze (another student of Marr's and co-founder of T.S.U.), for whom the exemplary dialects are the archaizing and "pure" dialects of the Georgian mountaineers. At this stage in the dialogue, the fields of Caucasology and Kartvelology emerge as antithetical reactions to Japhetidology, and the mutual process of polarization begins.

The third and final phase of the dialogue reverses the roles of Marr and the Georgians: Marr stands in response to the Georgians, Japhetidology in response to Caucasology and Kartvelology. (5) These disaffected Georgian students left Petersburg for Georgia after the Revolution, leaving Marr's Japhetidological project temporarily in a state of ruin. This institutional split allowed these differing opinions to become objectified in departments, disciplines, and scholarly publications; beneath this, the political conflict between Marr-an internationalist-and his nationalist Georgian students became fully voiced. Marr's Japhetidological project now moved away from Caucasocentrism, and the way is paved for the first major qualitative transition in his theory, from Japhetidology to the New Theory of Language.

\section{Indo-European Comparativism: Fellow Travelers Marr and Dzhavakhishvili}

Various biographical anecdotes depict Marr as an energetic but adversarial personality. Thomas (1957a: 325) notes "Marr's willingness, even as a student, to set himself against prevailing scholarly opinion." Thus, it should come as no great surprise that criticism was more likely to polarize Marr and his critic than lead to any sort of harmonization of views. The unifying thread of Marr's thought 
could almost be boiled down to a single dynamic of reaction, and his Japhetic antithesis to the Indo-European thesis was only the first of a long line of such reactions (such is the assessment of Smith 1991: 75-76). While his opposition to Indo-Europeanists dates from the beginning of his career (Thomas 1957b: 331; Slezkine 1996), this polarization appears to have become especially acute as soon as his work became accessible in translation to Indo-European scholars in Europe (in 1919), among whom it was not well received (Matthews 1949: 179). Their criticism led Marr to combat the comparativists even more strongly, and "by 1924-1925 his innate as well as outwardly stimulated opposition to Indo-European linguistics had become fully articulate" (Matthews 1949: 176). The confrontation continued throughout the late 1920s (Thomas 1957a: 334; Slezkine 1996: 831 note 19) and, indeed, until the end of Marr's life in 1934.

Thus it seems that criticism from the comparativist camp compelled Marr to entrench himself and may have been partially responsible for his moving ever farther away from the ideas and methods of the comparativists. However, Marr, while perhaps more expressive than others, was not alone: Ivane Dzhavakhishvili (d. 1940), his close friend, student, and colleague, was certainly a fellow traveler as early as 1902. What separates them is not the basis for their critique, but rather the response. Marr increasingly seeks to invert or subvert each of the methodological tenets and conceptual antinomies of Indo-Europeanism, initially by a kind of radical relativism, such that Japhetic simply has its own laws, its own psychology, and indeed its own modality of evolution, opposed to European categories at each point (Slezkine 1996: 832-33).

Dzhavakhishvili, a historian, certainly detected the colonial ideology underlying European views of historiography, but he did not feel compelled to throw out the received methodology as he critiqued its mistaken hypotheses. Marr could not be sanguine on issues of theoretical or political difference, and we find frictions arising in their close relationship as early as 1904-1905. We may surmise that their later scholarly antagonism was the result of a lengthy process of mutual distancing.

Marr consistently inverts the antinomies of Indo-Europeanist ideology. At times it is only this inversion that provides a unifying thread through Marr's thought, which is characterized by an almost single-minded reaction that works itself out variously in different domains (Smith 1991: 152-53; Slezkine 1996: 831-33). Thus, the evolution of Japhetic languages proceeds by a kind of plasticity that allows them to evolve into higher complex types by mixture, from simple languages with a correspondingly simple lexical inventory to multiply-crossed types that preserve these various natures intact within them. As has been noted many times, in Marr's theory, polygenesis by crossing moves toward a complex 
future synthesis, an inversion of the Indo-European monogenesis which moves toward diversity. 4 This crossing yields a "real heritage" which is to be opposed to the primarily ideological category of "lineage" that unifies the Indo-European group.5

For example, Marr in relatively late pieces like Rit cxovrobs iapet'uri enatmecniereba? (By what means does Japhetic linguistics live?) (1923b) constantly opposes the apparently utopian mixing of the Japhetic "dough" with the crisis of the coming of the "barbarian" Indo-Europeans, thus allowing the Völkerwanderung myth of Indo-Europeanism to persist, encompassed in a general Japhetic milieu. Marr's critique lumps Indo-Europeans and Indo-Europeanism into a transhistorical unity, having a twofold aspect: first, the Indo-Europeans destroyed the primal Japhetic unity, and second, the ideologists of Indo-European hypocritically denied that any such thing had happened, moving then to usurp the Japhetic cultural heritage as if it were in fact handed down by Indo-European racial lineage. Marr plays cultural heritage against racial lineage throughout this piece. European civilization is a Japhetic cultural heritage (memk'vidreoba), which Eurocentrist ideologues seek to attribute to an Indo-European racial lineage (chamomavloba) (56). This ideological inversion of history as revealed by Japhetic theory (which gives him his position of critique) is then the second problem of the Indo-European ideology. This dominant ideology, which is a reversal of the truth revealed by Japhetic theory, serves not only as a justification for the factual dominance of Europeans, but also as a truly hegemonic mode of oppression, which "enslaves formerly material slaves psychically" (58). Marr is therefore concerned that in the absence of a general unifying theory like Japhetidology, Japhetids would be relegated to a piecemeal facticity while the Indo-Europeans would be unified by a linguistic principle based on racial essentialism. "But for creating a real linguistics here there was no general ground: Here no such basis appeared, as Indo-European linguistics had discovered from its founding day in the general relatedness of Indo-European languages. Nor did general ideas exist here. On the contrary, there was and is enthroned today an extreme dispersion of investigative forces of scientific standpoints or particularities" (14).

The methodological dispersion of "Pre-Japhetidology" as opposed to the unity of Indo-Europeanism seems to have genuinely horrified Marr. Similarly, he felt that the ideology of Indo-Europeanism operated as a secularized ideology justifying European imperialism (directly paralleling Said's famous thesis to the same effect6-another "doublet"!): "Indo-European linguistics, exploiting the procédés of natural science, adopted the philosophy of a society based on religion and substituted linguistic for the religious divisions of mankind, isolated the 
Iberian languages. This is what Marr himself thought at one time. (Chikobava 1985: 48, emphasis added)

The languages listed are essentially those Marr claimed for Japhetic during his Caucasocentric period (before 1922), and it is clear that there is some justice in Marr's claims for the lack of originality of Caucasology.

It is not difficult to imagine that Marr felt betrayed, and it would thus not be surprising if this event contributed to Marr's further entrenchment, as well as to his continuing efforts to distinguish Japhetidology from everything else. While the "imperialist" ideology of great-power chauvinism latent in Indo-European comparativism had been one of his favorite targets, now the "nationalist" compartmentalization of disciplines by Caucasian (specifically Georgian) Caucasologists became a second bête noire. For Marr, an attack against a research methodology was a political disagreement.

\section{Conclusions: Marr's Final Abandonment of Caucasocentrism}

Marr's last publication in Georgian is Rit cxovrobs iapet'uri enatmecniereba? [By what means does Japhetic linguistics live?] (completed in 1922, published in 1923), which is the text of a lecture addressed to Georgian students abroad (delivered in 1921). It still shows some hope that the Georgians will change their minds and turn their focus to Japhetidological problems. After this point (1921) he simply ceases to address Georgians at all, aside from some occasional pieces on the Georgian language, and there are certain notes toward the end of the article which postdate it (1922) indicating some of the reasons. In the main section of the article, Marr notes with sadness that the Kartvelological discipline founded by Brosset has "flown" from its nest in St. Petersburg: "One hundred years have gone by since [the time of Marie F. Brosset], yet not one step forward has been taken - on the contrary, things have gone backward; however, in Petersburg the nest established by Marie Brosset has nearly become a desert for the lamentation of Jeremiah; that which has been created in Tbilisi-the Georgian university in particular-by the falcons who were raised [in St. Petersburg] but who have flown thence is indeed something which will have to be evaluated in the future" (Marr 1923b: 72-74).

Yet he Marr has not fully given up hope, even in these dark times (1921), of converting the university of Tbilisi from a (parochial) Georgian nationalist to a (scientific universalist) Caucasian internationalist university, the proper home of Japhetidology. "I also believe in the brilliant future of the Georgians' university of Tbilisi in our interesting field, if, understanding the universality of science, it realizes its rich possibility, to become a unified university of the entire Caucasus. 
chance to be published in the brief thaw after Marr's death in 1934. In this work, Dzhavakhishvili (1937: 10-13, 49-78) spends a good portion of his introduction criticizing Marr, in several places going so far as to say that he basically did not advance the discipline $(63,65)$. Arnold Chikobava, though not a student of Marr's, certainly had thorough exposure to his work. Despite that exposure, some of Chikobava's scholarship is very much in line with the methods of the Indo-Europeanists, such as his comparative Georgian-Mingrelian-Laz dictionary (Chikobava 1938). His position is certainly made clear by his initiating (or being chosen to initiate) the Pravda discussion of the official debunking of Marr's theories (Chikobava 1950), as well as an early confrontation with Marr at a lecture in Tbilisi in 1930 (reported in Dzhibladze 1988: 6-7).

Dzhavakhishvili (1937: 73) claims that one of the most ironic aspects of Marr's conviction that the Georgian students and scholars involved in the founding of T.S.U. were operating purely with nationalist motives is that if they really were nationalistically inclined, then they would have had every reason to embrace Japhetidology since (at least in 1918) it gave the Caucasians a central historical role in the development of world culture. However, it is clear that the winds of change were already in progress as Japhetidology spread, and it is equally clear that Marr wished to give these laurels to the united peoples of the Caucasus (including those who were "interlopers" from a Caucasological perspective, such as Ossetians and Armenians), and not the Georgians as a specific and separate group.

In any case, even though the work coming out of Tbilisi would soon show itself to be rather different from Marr's, around the time of the founding of the university in 1918 Marr seems to have believed that the Georgian scholars in Tbilisi were really practicing (or would soon be practicing) Japhetidology, but without giving him credit. Indeed, as far as content is concerned, Caucasology and Japhetidology at that time had essentially the same objects, if a different methodology. Chikobava's infamous condemnation of Marrism in Pravda, presents a story about Caucasian languages and culture which is essentially identical to Marr's Caucasocentric period classification:

The Japhetic languages (i.e., Ibero-Caucasian languages) ... are living representatives of an ancient group of numerous languages, the speakers of which were the creators of the ancient civilization of the Near East-a civilization that nourished Greco-Roman civilization, and hence, the entire culture of Western Europe. The dead languages of this ancient civilizationHittitel3 [?], Hurrian, Urartean (or Chaldean)-are neither Indo-European, nor Semitic and Uro-Altaic (this is the view of eminent authorities on the indicated languages). The languages just cited are peculiar; genetically they can be related to the equally peculiar living languages of the Ibero-Caucasian cycle (Basque included). We are confronted with an original world of Hittite- 
[natsional'no-romanticheski nastroennykh], but [who were] terrible theorists" (Marr 1918: 1501-02). Nor does it come as a surprise that he views their departure as a sort of defection or betrayal:

Concerning exclusively the matter of [founding a university with the curriculum proposed in the charter], I can with full conviction confirm that it attests to a deliberate break with the Department of Oriental Languages [in Petrograd], [to] a desire not to understand that without a close relationship to [the Department of Oriental Languages in Petrograd] in a single, rich program, the Georgian University will not attain any goal in its original Caucasological department: not only does work without such a scientific environment, [without] the assortment of closely related historical-philological and Orientalist sciences which we have at our disposal in Petrograd University, turn out to be of little use in itself, but soon [such work] depreciates specialists who are prepared to organize their own type of "secession." (1504)

What does come as a surprise is the following remark, in which Marr is discussing the courses of the proposed curriculum.

Everything which is passed off as an unprecedented novelty not only was planned long ago but has been accomplished and will be accomplished in Petrograd in the Department of Oriental Languages, from whose curriculum and surveys of teaching all the terms were borrowed, except one. The term "Japhetic" was expunged and in its place has been introduced the term "Georgian," in order to add (in the nationalist goals) to the specific term "Georgian" a general meaning just as if in Russian schools and in Russian science they established the term "Russian" to use instead of the term "Slavic," or even more so, instead of the term "Indo-European." (1502-03)

In other words, Marr seems to have believed that those students who had defected were planning to practice Japhetidology in all but name and that the charter's framers had nationalist motives for substituting "Georgian" for "Japhetic." The reason this is surprising is that the defectors did not end up toeing the line of Japhetidology down in Tbilisi.

For instance, Akaki Shanidze spends about a third of the preface to his dissertation criticizing flaws in Marr's work (Shanidze 1920: 4-5). The dissertation itself(Shanidze 1920a) is essentially a work of internal reconstruction consistent with the comparativist method against which Marr had set himself. Though the work of Marr and Brière (1931) is a reasonably straightforward grammar of Georgian, Shanidze (1980: 656) criticizes it as "not being free from the errors of the Japhetic theory." The work of Ivane Dzhavakhishvili (1937), though published nearly twenty years after the founding of T.S.U., is arguably an expression of sentiments that had been brewing for some time and only had a 
an "empty place" in Tbilisi which should be filled, but his Caucasian internationalism demanded a Caucasian university just as the political Georgian nationalism of his students required a Georgian university:

At the same time in the Caucasus, everyone sees one vacant place; it is a place which is empty in Tiflis in the absence of a state university and which demands filling. And the Georgian university naturally seeks to occupy it, as is obvious from several articles of its charter. ... In the development of the Georgians' national movement this is completely understandable. Tiflis is the center of the Caucasus, but at the same time, historically it is indisputably a Georgian city. . . . It is more important for us now to note that one hundred years of Russian administration not only changed its name (having expanded on this side of the Caucasus range and in connection with this having been christened "Kavkaz" [i.e., from its putative earlier name of Saqartvelo; see above]), but it has also changed inside, first of all, in the relationship of local peoples. . . . Thus Tiflis, unquestionably a Georgian city historically, after a hundred years of Russian government grew to be just as unquestionably the center of the whole Caucasus, which it is impossible to identify with Georgia. Tiflis for this reason is the center of the whole Caucasus not only administratively but also culturally. (1506-08)

As certain as Marr seems to be that the Georgians are not prepared to establish a genuine university, he is equally certain who does have the scholarly wherewithal. When speaking of the curriculum of the proposed university, Marr says: "The fact is that in the entire Caucasus, and generally outside of Petrograd, there is nobody who would be prepared to offer these courses" (1503). He also makes it clear that "Russian science" is in the best position to study the Caucasus, though he notes that the specter of Western European science, in the service of imperialism, is equally likely to appropriate the raw materials produced by such an underequipped university, "by leading into their own mill the cultural collaboration of Caucasian national scientific institutions": "In elaborating these rich Caucasian materials, Russian science, [which is] universal as [is] Western European [science], has a special right, since in many instances it has exceptional grounding for making an independent competent judgment, for making a correct decision of scientific tasks existing in world science in connection with the study of the Caucasus, e.g., on the cultural history of mankind in the region from the mountainous south of Russia to the Assyrio-Babylonian and Hittite countries" (1510).

Given this attitude it does not come as a surprise that Marr describes some of those who left St. Petersburg for Tbilisi as "a circle of my students [who were] idealists, or more precisely, [who had] nationalist and romantic leanings 
According to Marr, the sudden rise of interest in Kartvelology in St. Petersburg measures the slow (partial) eclipse of the social movement by the national movement in Georgia following the 1905 revolution. The 1917 political revolution in Georgia was the work of the Social Democrats, and whether or not it was "social in form, national in content" or vice versa, they had no direct role in the university. Therefore, the Georgian university itself, being independent of the post-Revolutionary government, was the only independent institutional expression of the cultural reform wing of the national movement, as Marr notes at the outset. In an irony familiar from other socialist countries (in general see Suny 1993, Slezkine 1996), nationalist ideology was often fostered as the content of "socialist" institutions, particularly universities. Moreover, such "nationalist" disciplines would be in a position to become a major beneficiary of rightward ideological shifts (cf., Kagarlitsky 1988: 128-35; Verdery 1991: 305-09; Saroyan 1996).

Concerning the planned university in particular, Marr maintains that "the goals of this Georgian university are not scientific in the first place, but rather nationalistic" and that the curriculum organizers are "nationalistically thinking Caucasian Caucasologists" (Marr 1918: 1504, 1505). In particular, he objects to the division of Caucasological disciplines on nationalistic bases into Kartvelology and Caucasology, presumably a problem that the spurned Japhetidology has transcended: "This is exactly why in the assumption for establishing the Georgian university, we observe the separation [vydelenie] of the Kartvelological parts from the Caucasological ones, a concentration of scientific thought in workrelated national goals primarily - or one might say exclusively - for the cultural aspects of life of the Georgian people, i.e., there appears a perfect substitution of scientific classification of historical-philological disciplines devoted to the Caucasus, by dividing on nationalistic bases the materials being investigated" (1505, emphasis added).

Marr believed that a chief defect of a nationalistically motivated university was that the Georgians did not "in reality have the scientific strengths or the scholarly institutions" necessary to "serve university needs" and consequently that national universities "do not guarantee to anyone, [not even] to the possessors of such national universities, a real university education" (Marr 1918: 1508, 1509). In addition, in a Georgian university, non-Georgian Caucasians would become "second- or even third- class citizens," which could only exacerbate nationalist sentiments in the multiethnic Caucasus and inevitably lead to "mutual misunderstanding and mutual hostility" (1509). In Marr's view, there was indeed 
Democracy a form of Russian treachery and turned away from the broader social movement, leaving them "ideologically isolated" even in the Caucasus. Marr adds that, as a result of this separation of the national movement from the social movement, "a sickly scum began to form on the health of the national movement," which was, unlike the social movement, limited to narrow circles (Marr 1918: 1497; cf. Suny 1993: 251). Marr then follows the slow transition of the social movement in Georgia and its leaders, the Mensheviks, into more and more of a national one, reaching a climax with World War I:

The World War . . which strengthened the nationalist trend even in Georgia, gave the advantage of ideology to growing Georgian nationalism and struck a severe blow to international social democracy. Social-democratic organizations maintained their strength, but in the Georgian environment, even if democratic, the appeal ceased to summon the old fervor which had shone on all the banners of the Georgian social movement of 1905-1906: "Proletariat of all countries unite!" In Georgia the motto, "Nationalists of all shades unite!" clearly began to take shape. Social democracy itself . . . and its independent representatives began to intersperse elements of Georgian nationalism in their doctrines. (149899)

If even the Social Democrats "could not escape baptism in the spirit of nationalism" (Marr 1918: 1500), then it would appear that the national movement had indeed moved up in the world, though always in the wake of the social movement. In fact, Marr's assessment of the Georgian Menshevik rapprochement with nationalism is, in broad outlines, fair enough (cf. Suny 1993). These changes sent ripples through the wide pool of empire: Marr claims to have witnessed from his post in St. Petersburg a sudden barometerlike change in the composition of the student body and a suddenly increased attendance in Kartvelology courses:

A wave of interest in national culture and, along with it, in studying the past not only increased, but overflowed into the broadest circles. This affected the barometer of the composition of the audience in the Department of Oriental Languages: Georgian students multiplied in the Armenian/Georgian category and they formed the main contingent in all the small auditoriums; a Georgian student circle affiliated with the department, under the guidance and with the lively participation of my Georgian pupils, pursued intense study of native culture, which was evident in the flood of Georgian students from all departments and even from the Higher Women's Courses to lectures on Caucasology, but predominantly to [lectures on] Georgianology [sic]. (Marr 1918: 1500) 
the peoples of the Caucasus share the same "autochthonous" roots, the same relationship to the mountainous landscape, and the same "cultural elements" that had emerged "from the treasury of the most ancient experiences of the people and found expression in original monuments." (Slezkine 1996: 836)

Marr's theories seem to have remained Caucasocentric on some level for some time. Having extended the scope of his discipline from the Pamirs (the "Central-Asiatic Caucasus") to the Pyrenees (the "Far-Western Caucasus"), he felt able to announce in 1922 that "Japhetidology stops being a Caucasian science" (Marr, cited in Thomas 1957b: 40). Yet we have seen that his methodology even at that point still posited Caucasian Japhetic as the methodological ground for Japhetic as a whole. As Matthews (1950: 4) notes, Marr's point of view in 1920 was still "caucasocentric" but "subsequently Marr was to modify these views, which in the course of time began to strike him as too 'caucasocentric"' (Matthews 1949: 182).

The founding of T.S.U. was significant for Marr in at least two respects. First, it seems to have exacerbated his general suspicions of the nationalist motives underlying such projects, being a "scholarly secession" paralleling the political secession of Georgia. Second, and more specifically, he viewed the departure of several Georgian students and colleagues in order to teach and study at the new university as a sort of defection. His 1918 statement on T.S.U., which was intended to be directly consequential when he first wrote it, offers some insight on these points. He begins with a little recent history: "The foundation of the Georgian University may be realized in revolutionary times, the project of its charter may be full of features brought in by the revolutionary mood, but the very thought of founding a national university among the Georgians emerged before the Russian revolution and was independent of its influence. It is connected with a new nationalism, which has obtained, unfortunately, a morbid and acute nationalistic character ... which began after the failure of the social movement in Georgia (1905-6)" (Marr 1918: 1496).

Marr viewed the revolution of 1905 , especially in Guria, as a purely social movement, not merely nonnationalist, but specifically antinationalist on the popular level. Nationalism came from above, in Marr's view. He claims that he personally witnessed Menshevik Social Democrats physically attempting to suppress popular antinationalist rhetoric (Marr 1918: 1496). This is possibly an exaggeration, since the Georgian Social Democrats had many different views on nationalism and were never as rigorously antinationalist as the Russian Social Democrats; nor, as Marr himself admits (1501), were they as nationalist as their rivals, the Georgian Socialist Federalists (Suny 1993: 251-52). As for the politically irrelevant "gentry nationalists," Marr claims that they saw in Social 
held sway in this commission, for the request was severely modified and made dependent on, and subordinate to, the Caucasian university that was Marr's own pipe dream. 12 Moreover, the reports given by the commission, especially that of 19 October 1917 (Dzhorbenadze 1984: 209-10), bear a striking resemblance to Marr's own separate statement published in 1918, suggesting that a large part of the commission's findings were taken from Marr's statement. As it happens, the rapid turnover of power made Marr's views and the commission's findings completely irrelevant: Lenin's policy of appeasing the nationalities, as well as the de facto independence of Georgia, dictated that the university would open on its own terms, even as a private university (Dzhorbenadze 1984: 210-11). Marr still felt it necessary to publish his statement, despite its status as a historical curio. It appears that the founding T.S.U. over his vociferous opposition was a crucial catalyst in causing Marr to become entrenched in his views and explicitly to oppose the philologists and linguists in Tbilisi, and vice versa.

Marr's Japhetic theory was Caucasocentric for much of his life. In a certain sense this was literally the case since up to about 1910 the Japhetic family included Kartvelian, from 1911 to 1916 included the entire Caucasus, and Japhetic later was conceived of as a stage through which other languages passed. Moreover, Marr's theoretical Caucasocentrism has as its political doppelganger his Caucasian internationalism, and since Marr himself moves with disquieting rapidity between these aspects of his thought, it is difficult to discuss them separately.

Matthews (1949: 173), speaking of Marr's politics as a student just after the turn of the century, says that "Marr himself admits that he had become a Caucasian 'internationalist' and was now strongly opposed to nationalist tendencies." What is meant by "Caucasian internationalist" is not entirely clear, but he appears to have favored something similar to Nikoladze's proposal for a "federation of all Caucasian peoples" (Suny 1996: 133), with Tbilisi as its center, as opposed to the Georgian nationalist project, which he calls a "political anachronism" (Marr 1918: xx). There is no question that for some time Marr had been developing an antipathy to nationalism in general and Georgian nationalism in particular: he found his counterpoint in an already existing version of internationalism on a regional scale. Slezkine, citing Marr himself, sums up Marr's political development as follows:

Even as a university student [Marr] "had stopped being a Georgian nationalist but had not given up the nationalist platform: as a result of dealing with the various national masses of the Caucasus and learning their languages he had gradually become an internationalist in his attitude toward Caucasian society." In other words, he had become a pan-Caucasian patriot, arguing repeatedly, passionately, and against vehement Georgian and Armenian opposition that all 
science. Indeed, his 1937 linguistic comparison of Kartvelian and Caucasian formed one of the volumes of "the study of the history of the Georgian people"! (cf. Lomtatidze 1968: 264).

T.S.U.'s mission and specific goal was indeed realized, to such an extent that it became the center not only of Kartvelology, but also of Caucasology: "Tbilisi University, in whose brilliant future Acad. Marr also believed, in spite of a full understanding of the 'universality of science,' never had any pretensions or desire to become 'the university of the entire unified Caucasus,' but in 1918, from the first day of [its] founding, it had already named as its goal and obligation, aside from [the scientific study of] Georgian and Kartvelian, the scientific study of Caucasian languages and culture, as well as the neighboring East" (Dzhavakhishvili 1937: 78). Not only would the Georgian university contain Caucasology as part of its overall mission, but it would become the center of the scientific study of the Caucasus: "Together with scientific research of the Georgian and Kartvelian languages, attention must be paid to the fundamental and deepened study of so-called Caucasian languages, for the very reason that this has supreme importance for understanding the original nature and later changes of Georgian itself. We must turn Georgia into the main center of research on these languages" (Dzhavakhishvili 1937b: 90). As Lomtatidze (1968: 272) notes in her assessment of Dzhavakhishvili's contributions to Caucasology, this project was indeed fulfilled on the eve of Dzhavakhishvili's ninetieth birthday, that "Georgia has really become the center of the study of Ibero-Caucasian Languages!"

Whether or not we see any particular problem with the explicit "nationalistic compartmentalization" of disciplines observed here, however obvious they may appear - and, we must admit, to us they are not at all obvious (cf. Irvine 1995) it is clear that there was one rather important dissenter to the envisioned project: Marr himself. And Marr was momentarily in a position to do something about it.

\section{Marr's Reactions to the Georgian University}

Tbilisi State University was founded in January 1918,11 though its proposed charter was formulated and published a year before (see Songhulashvili 2001). At this time Marr was in St. Petersburg, and he objected to the founding of a specifically Georgian university in Tbilisi, judging it to be motivated by nationalist sentiments rather than by the perceived need for a Caucasian university. His opposition was not an inconsequential matter of differing opinions for the Georgians: he sat on the higher educational reform commission that would decide whether the proposed university would receive a charter from the new, postRevolutionary government (Dzhorbenadze 1984: $207 \mathrm{ff}$.). His opinions clearly 
the university itself; this university becomes, for the nonce, the ritual center of Georgia's capital Tbilisi and thence of the Georgian nation as a whole. Indeed, the event apparently attracted the attention of "the entire city," "on the day of the defense the university filled with people" (Songhulashvili 2001:18): "I am very fortunate that fate cast to my lot the first deposition of a dissertation for a scientific degree in the first university of Georgia. I am so much the more fortunate that the topic of my dissertation is a phenomenon of the Georgian language and where, if not in Georgia; where, if not in our capital city; where, if not in the temple of Georgian science, should such a dissertation be deposited?" (Shanidze 1920: 1).

The Kartvelocentrism of Caucasology, as instituted at T.S.U., was latent in the proposed scientific mission of the university (a fact first noted by Marr, see below). Dzhavakhishvili's intent is summed up partially in the university's "specific goal." The "Georgian science" pursued at T.S.U. would have as its specific objects "Georgian and Caucasia." The asymmetry is more or less as Marr described it: the pool of empirical objects is "Georgia and Caucasia," but the discipline remains a specifically Georgian science. This Georgian science will make its national contribution to the international world of science by studying Georgia and the Caucasus. For Dzhavakhishvili, unlike Marr, cosmopolitan science is international in that it is built up from national contributions: "Dzhavakhishvili wrote that 'The Georgian university and Georgian science can show a necessary specificity and bring into world creativity its own particular contribution. ... Aside from general goals of science, Tbilisi University must have a specific goal named. This is the past and present of Georgia and Caucasia, its nature and humanity" (Dzhavakhishvili 1917, cited in Dzhorbenadze 1984: 192, emphasis added). The knowledge of Georgia cannot proceed without being properly embedded in knowledge of the Caucasian "context": "Even though, in my deep belief, as it has been shown that so-called Caucasian languages were languages of tribes related to our ancestors, every enlightened Georgian is just as obliged to know the history of these languages and tribes, as his own land and history" (Dzhavakhishvili 1937: xv).

Caucasology becomes a kind of ancillary discipline to the more basic and "obvious" discipline of Kartvelological self-knowledge and thence to the Georgia's own (national) contribution to (international) cosmopolitan science. "By the analysis of Georgian linguistic material alone the questions of the origin and the oldest culture of the Georgians are impossible to illuminate and decide. For this reason the use of ethnographic and linguistic materials of so-called Caucasian peoples and languages is still absolutely necessary" (Dzhavakhishvili 1937: xi). It is quite clear that Caucasology is focused on Kartvelology. It therefore was obvious to Dzhavakhishvili that it would logically be part of a Georgian 
The apparent Kartvelocentrism of this statement is a determined inversion of that favored by his students. Later on (Marr 1928), Marr seeks to use his etymologies to convert ethnonyms like kartveli into designations for class formations, "ethnoclasses," much as he had done, more famously and earlier, with Armenia (Slezkine 1996: 837).

Thus, each of the competing "-ologies" of the study of the Caucasus was initially Kartvelocentric, either implicitly or explicitly. Even when the purview of Japhetidology spread to Caucasian and thence to the world, it remained Kartvelocentric (under the rubric "Caucasocentric") methodologically. To claim that Kartvelology is Kartvelocentric seems tautological, but, as noted, this term has a hidden dimension that centers on Georgian (kartuli) and peripheralizes the other Kartvelian languages (kartveluri) in a similar manner (see Hewitt 1995 for a very informative, but polemical, discussion). Hewitt characterizes this as the "pan-Georgian doctrine," which he associates in particular with pre-Revolutionary personages like Gogebashvili (though many of its "planks" are still in place):

The essence of the "pan-Georgian" doctrine . . . despite refinements and slight alternations, has largely remained unaltered ever since [Gogebashvili]: Mingrelian and Svan are dialects/argots of Georgian, which latter is thus their mother-tongue; as mother tongue it has been taught in Mingrelian and Svan schools and has been used by them for writing and worship since Christianity arrives in the 4th century. Attempts either to teach, or encourage them to pray in, Mingrelian or Svan is [sic] tantamount to divorcing them from their common "Georgian" homeland, which would thus be threatened with division and disintegration. (Hewitt 1995: 287)

Such a view potentially had immense ramifications for the development of Georgian national institutions such as the lack of provisions for education in other Kartvelian languages or the uneven development of literary languages within Kartvelian, including the singularly striking inertia of Kartvelologists in providing Mingrelian and Svan with the paraphernalia of a standard written register such as dictionaries, textbooks, and so forth (Hewitt 1990; Hewitt 1995; Enwall 1992).

While T.S.U. was founded in 1918, only in 1920 when Akaki Shanidze deposited its first dissertation was it baptized as a true university. His remarks on this occasion (Shanidze 1920) underscore the felicity of the circumstance that the first dissertation deposited at the first Georgian university should have as its topic a "phenomenon of the Georgian language." T.S.U. thus became not only a Georgian university, but indeed a temple of the Georgian science of Kartvelology, with the Georgian language itself in the inner sanctum. The parallelism underscores the identity of the dissertation topic and the specific mission of the university itself. Moreover, this act is not merely felicitous for 
Under this account, the switch of kartveli from denoting "Kartlian" to "Georgian" never occurred at all, since the two had always basically been identical.

The goal of these terminological innovations was to provide an ethnonym for the presumptively unified Georgian-speaking ethnos (kartvelebi) who inhabited sakartvelo (see Hewitt 1995 for a general discussion of the "panGeorgian" doctrine in more detail). The fact that this innovative ethnonym is created by promoting a local ethnonym (Kartlian) to a national one (Georgian) is the source of some of the confusion. However, the real problem, as Marr saw it, was that the term was not being applied to everyone in Georgia, but only to an ethnolinguistic subset of them.

Marr, in his 1918 critique of his students, provides a striking counterinterpretation of the term sakartvelo as having a territorial range equal to that of the Caucasus (a continuing theme for Marr), and as having no pure ethnic correlate, using the putative archaic political and confessional senses of the term kartveli to undermine the novel ethnic (and therefore political) connotations favored by the Georgians. Thus, in order to combat the implication that the Caucasus is merely an epiphenomenal construct of recent political history, which elides the "true" ethnic protonations, he identifies it with various other political entities that have more or less corresponded to it extensionally:

Through one of the more numerous misunderstandings in the declarations of Russian society about the region concerning us, the Caucasus is considered a creation of the Russian bureaucracy - a region artificially cut out from the chance conglomeration of peoples and tribes. Moreover, the majority of contemporary representatives of the separate Caucasian peoples, and particularly the Georgians, think this in complete sincerity. In fact the Caucasus, as a whole, has its own, long, pre-Russian history and even a period of prewritten history. It does not change the essence [of the point] that in antiquity this actual Caucasus appears under the name of one or another tribe. These names did not always have a pure, single ethnic meaning; for instance, in antiquity neither the term Georgian (qartvel [Marr's orthography for kartvel]) nor the term Armenian (hay) had a purely ethnic-national meaning, but rather a religious-national meaning, and for that reason a cultural-national and politicalnational [meaning]. Qartvel in particular stood for practically the whole aggregate not only of Georgian and Georgian-related tribes and peoples, but also unrelated ones, provided that they entered into the composition of the Georgian group, sometimes a political [group], sometimes only a cultural one, but never ethnically only Georgian. In the golden age of Georgian history the term Saqartvelo [Marr's orthography for sakartvelo] stood for the whole Caucasus. (Marr 1918: 1506-07) 
there is the related problem of giving this newly extended ethnonym some "national" content ("Georgianness," kartveloba). In many ways, Kartvelology presupposes the former and projects the latter.

Part of the problem of finding a substantive content ("Georgianness," kartveloba) to attribute to nominal "Georgians" (kartvelni) was that the latter term itself had only newly been applied to Georgians as a whole. Partially as the result of nineteenth-century terminological innovations, the term kartveli came to be permanently disassociated from the term kartli and associated with residents of sakartvelo instead, but, of course, not just any residents. For example, an Ossetian will always be an Ossetian, just as an Armenian will always be an Armenian, and any Turkic Muslim will always be a Tatar whether he speaks Georgian or not. Dmitri Qipiani wrote in 1853 that "today it is the Kartvels residing in the Governate of Tbilisi [Eastern Georgia, including Kartli] who are called kartvelebi" (cited in Hewitt 1992: 256-57), which is a reliable account of one of its more common meanings in nineteenth-century texts. However, he moves easily from constative "is" to performative "hereby shall be" when he reextends the term more broadly by performative baptism to "residents of sakartvelo" (but, it should be noted, on an ethnic basis): "nevertheless to this tribe we shall assign not only the Imeretians and Gurians, who spoke one and the same language and were of the same religion before the time of Parnavaz, but to this tribe also belong the Mingrelians, Abkhazians, Svans" (ibid.). This (partial and selective) conflation of kartveli with sakartvelo, once achieved, has been projected into the primordial past by Georgian academics. In particular, a term that originally designated the shifting political boundaries of the Kartlian kingdom or the area in which the Orthodox liturgy was performed in Georgian, with no more ethnic or national content than the monarchy or the church itself, came to be given such content retrospectively. Sometimes the two territorial moments of the term are joined retroactively, so that kartli itself was also always sakartvelo. Witness the particularly egregious presentism of the following recent assessment of Georgian national prehistory:

From time immemorial Georgian (Kartvelian) tribes settled in their country in a solid mass. They began early to rally round their principal national and cultural core, the Kartlian tribe. Owing to this, they developed early a sense of national community which later on became ever more consolidated and broad. This unity was also based on the linguistic unity of the Georgian tribes. According to some educated Georgians, in the sixth and seventh centuries, the concept of "Kartli" included the natives of both eastern and western Georgia. (Dzidziguri 1969: 9) 
This leads to the ambiguity inherent to the name kartvelologia. Kartvelology is the science of kartveloba, the ethnolinguistic study of kartvels. The ethnonym kartveli corresponds to two nodes in a family tree, both the specific groupGeorgians in sense (2) - and the more inclusive grouping-Kartvelians. Thus, Mingrelians and Svans, speakers of Kartvelian languages, are kartveli ethnically, whether or not they also speak Georgian. However, not everyone who speaks Georgian is a kartveli; for example, Armenians and Ossetians are not Georgians even if they live in Georgia and speak Georgian. It is perhaps this scholastic impasse that led Gogebashvili to declare that Georgian was the "mother language" of the Mingrelians and Svans (even if they did not actually speak it), and Mingrelian and Svan were simply local "dialects"! (Hewitt 1995).

The term kartveluri, as well as, obviously, the name of the discipline kartvelologia, are later introductions based on the ethnonym kartveli, whose ambiguity results from being opposed potentially to other terms at several levels of taxonomic contrast. As a result, the term has some of the qualities of an "ethnic shifter," that is, a term whose reference varies contextually (on ethnic shifters and nationalist discourse see Herzfeld 1987: 154-57). The most weakly developed sense of the term is the civic one ("citizen of Georgia") or indeed, the purely linguistic one ("Georgian-speaker"). Rather, the definition moves queasily among ethnic, linguistic, territorial, and confessional logics so that Armenians, Ossetians, "Turks," and "Tatars" will be excluded but Svans, Mingrelians, and sometimes Abkhazians will be included. Not only does Kartvelology as a discipline echo this quasi-ethnic, quasi-linguistic logic, but indeed, the absorption of the Kartvelians into the Georgian (Kartveli) ethnos is a direct consequence of this logic (for an example see Itonishvili 1990).

The disciplinary unity of Kartvelology, as should be obvious, presupposes a notion of national unity that was constructed in a particular way in the nineteenth century. It involved simultaneously a presumption that the ethnic term kartveli should be extended to cover the presumed ethnic unity that was Georgia, and that, conversely, the term "Georgia" (sakartvelo) should be given a specific ethnic content that presumed not only "Kartvelianness" but also a narrower "Georgianness" in the sense of speaking Georgian. Thus, there are really two things at issue that are nineteenth-century inheritances of Kartvelology. On the one hand, there is the extension of the ethnonym kartveli from being a narrow designation of a small portion of Georgia - namely, Eastern Georgia, Tbilisi region, in contrast to imereli (Imeretian, Kutaisi region) with which it is often opposed in nineteenth-century texts - to Georgia as a whole; on the other hand, 
"figure" from a "ground" of mixture, thus at the same time affirming a transhistorical territorial unity (Georgia) and denying a good many of its denizens any connection thereto as Georgians.

In regard to the first matter, Kartvelology as a discipline has an ambiguous object, inasmuch as it is named for only one of its ethnolinguistic parts, the kartvels (as opposed to Svans, Mingrelians, and Laz). As a result, the ethnonym kartvel potentially corresponds to at least three broadly distinguishable levels of inclusion separately denotable adjectivally (Itonishvili 1990: 19-20):

(a) As a term (now obsolete) equivalent to the modern neologism kartleli "Kartlian," meaning an inhabitant of the district of kartli (where Tbilisi is located, as opposed to $k^{\prime}$ axeti, guria, and so on) or the dialect thereof (adjective: kartluri);

(b) As equivalent to the adjective kartuli "Georgian(-speaking)," which refers to things Georgian (especially the Georgian language), as immediately opposed to the other Kartvelian languages (Svan, Laz, Mingrelian);

(c) As a rough extensional equivalent of the medieval term sakartvelosani "of Georgia," as the ethnonym corresponding to the territorial term sakartvelo (and it would be a mistake to claim that there is any relationship between the medieval intensional meanings of this term and the modern meanings); this latter is apparently an innovation from (b), leaving a gap to be filled by the neologisms kartleli, kartluri "Kartlian."

This results in potentially three separate senses for the single ethnonym Kartveli, one of which is obsolete and another is a recent innovation (from the nineteenth century) (Itonishvili 1990: 19-20). Of these, sense (2) is the most current.
(1) Ethnonym
Intension
Correlate
(2) Kartveli
territorial
linguistic
(3) Kartveli
territorial
Kartli (Tbilisi region) (obsolete)
Kartuli (Georgian-speaking)
Sakartvelo
(Georgia)

However, the ethnonym kartveli can also correspond to the neologistic adjective kartveluri, which refers to the languages most closely related to Georgian: Mingrelian, Svan, Laz. For speakers of these languages, there is no corresponding ethnonym, but rather, these are included under kartveli in a subsense of (2), namely (2'):
Ethnonym
Intension
(2) Kartveli linguistic
Correlate
(2') Kartveli linguistic
kartuli (Georgian-speaking)
kartveluri (Kartvelian-speaking:
Georgian, Mingrelian, Svan . . .) 
the ground. Thus, Japhetidology is, at the time of the founding of T.S.U., a more or less Caucasocentric discipline, which seeks to refer non-Caucasian Japhetic languages to the privileged ground of Caucasian Japhetic languages. This tendency toward a kind of methodological homology of Marr's political Caucasian internationalism finds expression in various ways, and has certainly been noted before (e.g., Matthews 1949; Thomas 1957b; Slezkine 1996).

Similarly, Dzhavakhishvili's Caucasology centers on Kartvelology, specifically as a form of knowledge necessary for the development of the national self-consciousness of the Georgian people. Caucasology would have Tbilisi as its institutional center (similarly for Marr); it would be a discipline conducted through the medium of Georgian primarily, primarily by Georgians; and its scholarly products would be intended primarily for a Georgian audience. This latter fact leads to a certain confusion between Caucasology and Kartvelology, as Marr himself notes (cf. also Charachidze 1959: 71). Clearly, if Japhetidology has as its political homologue Caucasian internationalism, both Kartvelology and Caucasology could also have homologues in one or another form of Georgian nationalism, as Marr perceptively observed. In Marr's view, the ethnohistorical, rather than civic, basis of Georgian nationalism could easily move in two complementary directions, leading "inevitably either to the separation of Georgia from the pan-Caucasian complex or to the restoration of the past hegemony of the Georgian people over the Caucasus in general" (Marr 1918: 1501). It would not be difficult to see Kartvelology as the ideological expression of the former tendency and Caucasology, as constituted, as an ideological expression of the latter.

Likewise, the Kartvelian languages (Georgian, Laz, Mingrelian, Svan) are dominated by a Kartvelological discipline, and only thence by a Caucasological one. Thus, Kartvelology shows within itself a curious ambiguity and asymmetry between its parts: there is a strong asymmetry between the role of Georgian and its dialects, on the one hand, and the other Kartvelian languages, which are effectively reduced in stature to "sociolinguistic dialects" (Hewitt 1995; 305; correspondingly, their status as separate "ethnos" is hotly rejected by Georgian scholars [Itonishvili 1990]). This asymmetry works itself out in practical terms, especially in terms of development of literary languages (Hewitt 1990; Hewitt 1995). Moreover, the field of Kartvelology, although in many ways the least novel of the three "-ologies" in its ideological underpinnings, also presumes and projects a unified national object based on multiple overlapping criteria, mostly ethnic and linguistic. Kartvelology sought to extract a pure ethnic or linguistic 
should operate on the same essentially nationalist principles as it did in Europe, it was not quite so obvious to Marr. At the risk of imputing too much reason to the ravings of a self-confessed "madman" (Slezkine 1996: 838 note 18), we should note that Marr's critique of ideology parallels more recent critiques of language ideology:

There is a growing awareness among linguists, historians and anthropologists
that our conceptual tools for understanding linguistic differences still derive
from this massive scholarly attempt to create the political differentiation of
Europe. What is less often remarked is that the intellectual justification of
today's disciplinary division of scholarly work on language derives from the
same source. For example, within the social sciences, the persistent use of
language as a synecdoche for community relies unquestioningly on the
supposedly natural correlation of one language with one culture. . . [T] [Te
reliance on an empirically inadequate assumption that each language is linked
to one culture [has] its consequence-the relative neglect ... of linguistic
variation, multilingualism, and patterned social functions of speech. (Gal and
Irvine 1995: 968-70)

By the time T.S.U. was founded, the study of the Caucasus had produced three new disciplines, three great "-ologies," with differing relations to their area of origin: Marr's Japhetidology, Dzhavakhishvili's Caucasology, and Shanidze's Kartvelology. Their empirical scope and theoretical programs can, at first glance, be seen as having a relation essentially of vertical taxonomic inclusion. For a time Marr could claim that either Kartvelology or Caucasology was simply a new name for Japhetidology, and it is also true that Caucasology had claims on territories and irredenta beyond the Caucasus (including many of those which Japhetidology had already claimed, for instance, Basque), just as much as it made no claims to certain peoples within it (for example, Ossetians, Armenians, "Turks," and "Tatars"). The central difference, as Marr himself was the first to articulate, was that Caucasology (like Kartvelology) assumed a unifying genetic relationship, leading to the exclusion of known Indo-European or Turkic groups from the magic circle of Caucasology, while Marr sought other, more flexible criteria of inclusion. Soon after the schism between these fields, Caucasology would remain unchanged in its purview, while Japhetidology would continue its expansion. It thus has a dynamic relation to the other two disciplines, which are like ossified husks cast off by the ever-growing and omnivorous Japhetidology.

From the way in which these fields were constituted, they can be seen to have a horizontal structure, so that a lower taxonomic term becomes the thematic "center," "figure," or "focus" of each higher taxonomic term, which serves as 
Caucasus as a whole. To this ambiguity of center there was a corresponding ambiguity at the periphery: the Terek River was universally understood to separate the Caucasus from Russia proper (Layton 1986: 477; Layton 1994: 92), and this river, so central to Russian imaginings of the Caucasus (Layton 1994), also gave the tergdaleulni (those who have drunk from the Terek river)-St. Petersburgeducated, Georgian intellectuals of an earlier generation-their name (Suny 1988: 125-26; Rayfield 1994: 174). Given this peculiar conflation of geographical entities, it is not surprising that a proposed university in Tbilisi could be understood to be the institutional center of scientific study of either Georgia (Kartvelology) or the Caucasus (Caucasology or Japhetidology) or both and, what is not quite the same thing, it could be understood to serve the scientific and educational needs of either Georgia (a Georgian university) or the Caucasus (a Caucasian university). Thus, Tbilisi could be the center of both an object of investigation (Georgia, the Caucasus), and of the investigating subject (a Georgian or Caucasian university), and these need not be in any kind of alignment. Hence, Dzhavakhishvili's Caucasology would be-somewhat paradoxically - a Georgian science: the study of the Caucasus by Georgians.

In the debate that opened between Niko Marr and his first generation of dissident Georgian nationalist students, there was no question that Tbilisi was the central point, and the only question was, Center of what? Marr, as late as 1921, was calling for T.S.U. to have a "brilliant future" in Japhetidology, while Dzhavakhishvili hoped that it would become the center of Caucasology, and Shanidze inaugurated the university by depositing a dissertation on Kartvelology. Regarding the question of whom the university was to serve, Marr broke sharply with his erstwhile Georgian students, calling as late as 1921 for "a unified university of the entire Caucasus" so that non-Georgian Caucasians would not be second- or third-class citizens. Dzhavakhishvili and Shanidze both saw Tbilisi as the natural home of the Georgian university, Dzhavakhishvili arguing that while T.S.U. could fulfill the scientific mission of Caucasology, it had no such pretensions to become a "Caucasian university" (Dzhavakhishvili 1937: 78). Marr saw an asymmetry here: the university would serve Georgians, but not the Caucasus, yet it would help them know both themselves and the Caucasus as a whole. Marr saw more than a mere homology between academic discipline and political utopia.

Marr's critique of his students, in particular the "nationalist compartmentalization of disciplines" (see below) and the homology between disciplinary and national boundaries, was particularly prescient of later critiques (Irvine 1995; Gal and Irvine 1995; Gal and Woolard 1995 among others). However obvious it may seem today that discipline formation in the Caucasus 
methodology" (Thomas 1957a: 329). This elucidates how it was possible for Marr to expand Japhetic to include ever more orphaned languages, as well as some of the radical mutations in the theoretical grounding by which these new adoptees were accommodated. A good portion of the drive for the theoretical changes of this period can also be explained by Marr's own telos, to resolve the "Great Ethnological Predicament" once and for all (Slezkine 1996), simply by a process of unending inclusion. Lastly, some of the changes in purview of his theory can be explained by the pragmatic difficulties of actually reaching the Caucasus during the end of the Great War and the bloody aftermath of the Russian Civil War (Clark 1995, citing Marr himself). Left unexplained, however, are the simultaneous impulses to move Japhetic beyond the Caucasus, as well as against Caucasocentrism (in a theory for which the Caucasus served as the semiconcrete, semiabstract ground) around the same time as these other impasses were reached. Moreover, while Marr's mind never shied away from ferreting out further ethnolinguistic orphans, his new acquisitions after 1917 tend to be scattered far and wide. Surely a mind possessed of as fervid an imagination as Marr's would not allow inconsistency or baroqueness to interfere with his imaginings, no matter how many layers would be revealed in his native Caucasian languages by the need to accommodate these new-found kin.

This particular move, which in itself may have had many further consequences, was more probably in reaction to an event that would have been scarcely of interest to onlookers from Europe or Petrograd. This catalytic event was the founding of Tbilisi State University and the sudden departure of Marr's first generation of students, including close friends as well as countrymen, taking with them, as he saw it, not only their company and collegiality, but also his theory, under different names (Kartvelology and Caucasology). This event represented a crisis for Marr on a number of different levels (institutional, theoretical, personal), and could only be overcome by a radical restructuring of the methodological ground of his theories. Thus, we come to a second decisive stage in the dialogue between Marr and the Georgians, where the potential and growing differences of emphasis among colleagues discussed above have become actual and definitive divisions backed up by institutional and national secession.

\section{Disciplines and Nations: The Founding of Tbilisi State University}

As Marr noted in 1918, the existence for one hundred years of a Russian administrative unit called the "Caucasus," governed from its capital in Tbilisi, had created a situation where Tbilisi became the center of more than one geographical construct (cf. Rhinelander 1996: 87). While Tbilisi was in some sense a Georgian city, indeed, the center of Georgia, it was also the center of the 
Thus, by some curious alchemy, a contested issue and source of division between Georgians and Armenians in fact becomes a binding myth and the basis of pan-Caucasian unity, centering on the primordial Meskhs (now the Hayk', elsewhere an ethnonym related to Armenia), whose main distinction as an ethnos in Marr's theories from at least 1910 is to appear as components of other ethnicities, languages, and cultures: "In the Georgian language ... as is wellknown, two languages-Kart and Meskh, just as closely related to each otherwere fused" (Marr 1910, cited in Thomas 1957b: 13).

The existence or unity of Georgia (Sakartvelo) never had anything to do with the region of Kartli or the monarchy whose political power emanated therefrom, but was yet another Meskh contribution. Moreover, in what is by now a commonplace in Marr's rejoinders to the Georgians (see below), the term sakartvelo always meant "Caucasia," never "Georgia."

Georgia [sakartvelo] did not represent the ethnographic Kartli even formerly; there was a still earlier unity of peoples, a totality based on the satisfaction of the psychological and economic requirements of all united peoples forever. This complex totality guaranteed, among other things, the rejuvenation and development of free cities, the creation of a local bourgeoisie of Caucasians. One example: real national development and art which had been poured out in national dialect, especially architecture, never flowered so much in Armenia, as in the city of Ani precisely when it formed part of the unity of Georgia. Although provoked by the material requirements of life, the historical theory of "Haosness" [the reference is to Armenia] of the Georgians was not an invention or, as Professor Patkanov thought, the fabrication of an ignorant Armenian monk to diminish Georgianness; [rather,] this was a historical fact spouting out from the bosoms of old ethnic traditions. In order to demonstrate its independence from Armenian ill-will it suffices that we remember that "Hayk" means or represents the ethnic term "Basque" or "Meskh," and aside from that, [given] what great work the Meskhs have performed in the creation of Georgian culture, does anyone now undertake to deny the importance of the same tribe of Meskhs in the creation and development of the ethnic type of Georgians? (Marr 1923a: 62-64)

The final sacrifice of the Promethean culture-builders, the Meskhs, was virtually to disappear into the Kartlian ethnos they had created, as they had vanished, under the rubric "Haos"/"Hayk'," into the Armenian ethnos and language, and under the rubric "Basque," into the Gascon dialect (Marr 1923a: 26). The ethnonyms of the Meskhs are legion.

Marr's constant empirical expansion of Japhetic beyond the Caucasus into Europe and the Near East from 1917 on, as well as the resulting theoretical contradictions and aporias, can be explained by an "immanent" account that locates the impulse for these changes as "a direct consequence of Marr's own 
the sacred center of Georgianness, had become a profane periphery populated with Georgianized "Tatars" or "Tatarized" Georgians. Marr's preternatural ability to essentialize groups temporally across thousands of years allowed him simultaneously to identify the Meskhs with extremely archaic ethnonyms (mosokhs) and at the same time with these Islamicized modern inhabitants, symbols of Georgia's internalized Orient and therefore its mediating position between Islamic East and Christian West. The Meskhians, so understood, had the hybrid quality Marr so favored, and moreover can be taken as a dialectical negation of Pkhovian, standing as impure Georgians as opposed to pure Georgians, a symbol of progressive proto-internationalism to the backwardlooking gentry nationalism symbolized by Pkhovian.

Marr's championship of the Meskh contribution to Georgian and thence to Japhetic culture is manifested linguistically by finding Meskh layers everywhere in every language, aided later by his identification of Basque with Meskh (Marr 1923a). (See also the extraordinarily important place Marr gives this dialect in figure 1.) The Meskhs, paradoxically both mixed themselves and one of the elementary components of further mixtures, appear as layers in every language. One of the most important Meskh contributions was in Marr's finding that the Armenian ethnos was a blend of Svan (Son) and Meskhs (Mesx) giving rise to a blended etymology of the Georgian word for "Armenian" (son-mesx @ somex'Armenian'). The Meskh contribution was also manifested culturally by Marr's claim in 1917 that Rustaveli, the central figure of Georgian literature, was in fact doubly peripheral (Muslim and Meskh), and that therefore Rustaveli's language was Meskhian. The Meskhs become the exemplary Georgians (indeed Caucasians), just as for Georgian nationalists the equally peripheral Pkhovians are exemplars of a lost simplicity and purity. The movement of the Meskhs (who are, empirically, at best one of many Georgian dialects) from the periphery to the center of Marr's version of Caucasocentrism has hardly been commented upon, but by 1920 (Marr 1923a) they turned out to be the key component, the foundation, of Caucasian unity, inasmuch as they were not only the same as the Basques (Marr's new favorite at this time), but also they were the basis of the Armenians, as the mythical Hayk'/"Haos" (ibid; see also Thomas 1957a: 49).

In Basque we have a surviving representative of a spirant language, but an already hybridized one, mixed with related Japhetic languages. ... . To all appearances this is that spirant language which has left layers in the hybrid languages of the Caucasus-Old literary Armenian, Svan, and Abkhaz, and part of which directly or indirectly fused with Georgian. This is the language of the tribe of masks//moshoxs//mesxs-a term which has been preserved for the Basque people by the peoples surrounding them. (Marr, "On the Japhetic Origin of the Basque Language" [1920], cited in Thomas 1957b: 49) 
dying down, and in the sixties the folk dialects were already victorious. Almost every connection to the old literary language was broken, but, since the national [erovnuli] pulse is weak, the forging of a general literary language has been delayed and today this process is still unfinished. (Shanidze 1915: 9-10)

In sharp contrast to Marr, Shanidze downplays the role of Persian elements in the revitalization and subsequent reformation of registers in the Georgian literary language. The contrast between Marr and Shanidze is at this point one of emphasis, but is still rather striking. For Shanidze, foreign influences are present as minor players in national struggles: the Mongols have a purely destructive role, clearing the playing field, while Persian influence is conceded a minor part in the literary renaissance, firmly subordinated to the role of folk dialect and genre: "Persian influence assisted the renaissance of national [saero] poetry in Georgian literature, it is true, but it [viz., national poetry] had a ground in folk [xalxuri] poetry and therefore in folk [xalxuri] dialects" (Shanidze 1915: 9). Yet the folk (xalxuri) tradition would have to bow before the national (saero) tradition. Folk traditions, and especially dialect, would ultimately have no organic place in most literary registers except as a lexical fund, quarries of lexical elements (pormebi) to be used to build a standard register (cf. Dzidziguri 1987: 56; Dzhorbenadze 1984: 178-80). Folk dialect becomes the organic complement to an inorganic, national literary language, a constant source of renewal, a lexical treasury, another form of folk diversity from which national unity is to be fashioned (for parallels see Hofer 1980). Any literary role of dialect would be limited to poetry rather than prose. It is similarly noteworthy that Kartvelology had no place for more than one literary language within the South Caucasian language family. All such languages became spokes around the hub of the Georgian literary language; they were separate languages only in a formal sense and would be functionally little more than dialects. Attempts to formulate a separate Mingrelian or Svan literary tradition, beyond folklorist chrestomathies, were not fostered (or, some claim, were actively opposed or diverted) in the field of Kartvelology or in language planning (cf. Hewitt 1990: 133 ff.; Hewitt 1995; Enwall 1992 for a survey of Georgian nationalist rhetoric on the literary status of Mingrelian).

Both Marr and Shanidze found inspiration in a peripheral dialect as a model for Georgian, a kind of "peripherocentrism." For Shanidze, following Vazha Pshavela, the key peripheral dialects were the Pkhovian mountain dialects, whose archaicism and purity were born of isolation and for whom nothing would be more fitting than an archaic ethnonym. For Marr, the Georgian dialect of interest is Meskhian. In the late nineteenth century, the Georgian intelligentsia had identified Meskheti as the center of an earlier flowering of Georgian culture, including, for example, Shota Rustaveli.10 The irony was that this region, once 
As shown above, Shanidze also praises the Pkhovian dialects for their archaicisms, which make them useful for the reconstruction of Old Georgian.

In the remainder of the piece, Shanidze tells a story-one that harmonizes in broad outlines with other treatments of this subject in Georgian nationalist thought - of a ruptured literary tradition that was originally based on ecclesiastical registers. Somewhat surprisingly, the Mongols and folk dialects emerge as unlikely heroes in ridding Georgia of a senile literary language. This language was on the verge, according to Shanidze, of solidifying its influence in every field and eliminating every dialect (it is not clear whether he means "from literature" or "from the face of the earth"), but was prevented by the birth of a national poetic tradition (from below) and the Mongol invasion (from above). "In the eighth century the literary language was worked out (completed) and in the tenth century developed to the highest degree; it was already a sharpened weapon in the hands of ecclesiastical writing and sought to rule everywhere and in every sphere, to devour and wipe out dialects. But two circumstances prevented this: the origination of national [saero] poetry of the eleventh century and its marvelous flowering in the twelfth century, on the one hand, and the Mongol invasion in the thirteenth century, on the other" (Shanidze 1915: 9). Here, by emphasizing a tension between ecclesiastical and folk (xalxuri) or national (saero) elements in the literary language, Shanidze's view has parallels to Marr's, but with important differences. Shanidze sees the conflict as being contained within a national culture, while for Marr, at least at one point, both these opposed poles would derive from different foreign sources: ecclesiastical elements from the GrecoArmenian Christian Occident, folk elements from the Persian and Muslim Orient.

This conflict is at first glance merely a continuation of the well-known intergenerational conflict within the Georgian intelligentsia of the sons (Ilia Chavchavadze and company) with the fathers over the "three styles" in the 1860s (Suny 1996b: 126; cf. also Hewitt 1990). Indeed, Shanidze makes these later debates about language the coda of the ongoing, virtually transhistorical, struggle between folk and ecclesiastical norms, and he rather strongly sides with the victorious folk. However, he sees setting up a new literary language as an event delayed by the weakness of the national pulse.

The Mongol invasion cut off the triumphant course of the ecclesiastical literary language, also impeded by national poetry. A firm tradition was destroyed and a wide field opened up to folk [xalxur] dialects in life and literature also. This phenomenon became stronger in the seventeenth and eighteenth centuries, and although at the very same time they tried to return to old forms, to imitate classical writers and to restore their language, provincial forms gradually took an honorable place in literature and especially in poetry. In the first half of the nineteenth century the battle of these two orientations (of old and new) was 
Intelligentsia were not confirmed" (this is all we learn from Dzidziguri 1987: 56). We also see a sudden, striking shift from the radical underground publications of 1906 to a series of seemingly fairly innocuous folklorist pieces on Pshavian folktales from 1908 on (Dzidziguri 1977: 64-65). By now, it seems, whether or not Shanidze remained, or ever had been, a scientific anarcho-syndicalist in the manner of Kropotkin, he was now by his own confession a nationalist (Dzidziguri 1987: 5-6). He met the aging Romantic poet Vazha Pshavela through his brother, Beso Shanidze, in Pshavi around 1908, and stayed with him in the village of Chargali during his field trips to Pshavi in 1911-1912, with Vazha Pshavela acting as his guide to Pshavi (Dzidziguri 1987: 9). Vazha Pshavela was very excited by the project that brought Shanidze there, and Shanidze seems to have held Vazha Pshavela in equally high esteem: "While leaving Chargali, Vazha pointed out the hill of Chargali and said, 'Here I must be buried.' Akaki Shanidze answered him, 'Your grave site is Mtatsminda in Tbilisi, which must become our pantheon"' (9). Perhaps only by coincidence, Shanidze's pioneering publication on the dialects of the mountaineers was published the year of Vazha Pshavela's death, 1915.

The particular importance of the "Pkhovian" mountain dialects in the revitalization process is a fairly clear inheritance that again places Shanidze partially in the tradition of the Georgian Neo-Romanticism of Vazha Pshavela and to a lesser extent the more generic romanticism of the gentry nationalism of Ilia Chavchavadze. Consider the pivotal role Vazha Pshavela accorded the Pshav dialect (which for him is "Pkhovian") because of its purity and its archaism. Indeed, he identifies it with Old Georgian in so many words:

The modern literary language is new and because of its novelty it lacks many forms, many words. All these forms and words are preserved among the folk; the folk [xalxi], the people [eri] is the mother of language. It [the people] gives birth to and raises language, as a mother does a child. Every ethnographer and every national [saero] writer is obliged to make known to the literary language every notable folk [xalxuri] word or form, if this word or form corresponds to the character of the language, to its nature. If the language adopts that form, that word, fine, if not, there is no harm in it. ... The Pshavs have an honorable position in this respect. The dialect and forms of their conversation are noteworthy, among other reasons because they have had greater means to preserve the Georgian language purely, unbesmirched: the Pshavs (the Pkhovians) have had less influence from Ottomans, Persians, Arabs, and so on. For this reason their communal dialect (if we can call their conversational language a communal dialect) and grammatical forms are ready to be used [and] worthy of being known. The dialect and grammatical forms of the Pshav conversation, as real Old Georgian, completely resemble the old written manuscripts, because of which they do not represent a "step backward." (Pshavela 1888: 632-33, emphasis added) 
Vazha Pshavela, whom he met in 1908 (Dzidziguri 1987: 9); both stood at this point, by their own confession, in the same camp as Ilia Chavchavadze's "gentry nationalism."

We do not know the full extent of Shanidze's linguistic purism, though we do know that not only was much of his scientific work in one way or another devoted to the practical goal of language reform (Dzidziguri 1987: 68-71), but he published and lectured on this topic throughout his life. Much of his scientific work proceeded with a view to grounding the "normalization" of the Georgian literary language scientifically (68). This seems to mean a fairly straightforward romantic organicism (as opposed, for example, to some sort of quasi-utilitarian principle of simplification), 9 grounding reform in the language's empirically revealed internal laws: "Our scientist [Shanidze] requires that the literary language should accept as norms those forms which correspond to the nature and specificity of the Georgian language, the structural peculiarities of the Georgian language" (68). Without desiring to oversimplify his position, we might simply say that, with many, but not all, language reformers across Europe, Shanidze's purist tendencies seem in general to have led him to reconstruct old norms rather than construct new ones, a phenomenon that Haugen (1969: 291) calls "archaicizing". Whatever the details, Shanidze's approach was much more conservative than Marr's, and he clearly preferred to keep any mixture in accord with the existing nature of the language, while Marr insisted that the mixture went far deeper.

Shanidze's political views are somewhat enigmatic, unlike those of his official mentors in St. Petersburg, Marr and Dzhavakhishvili, both of whom were engaged, critical intellectuals, typical scholarly members of the Russian (or East European) intelligentsia (Confino 1972; Bauman 1987). After the Revolution of 1917 Shanidze is, in sharp counterpoint to Marr, the archetypal objective scientist. Before the Revolution we can catch glimpses of a seemingly rather different youth. In the aftermath of the Gurian uprising of 1905, the young Gurian Shanidze, working under a pseudonym, while still a gymnasium student in Kutaisi, translates Kropotkin's "Modern Science and Anarchism" into Georgian for the paper Musha (Worker) in 1906, and writes, along with his colleague Qipshidze, a short piece of unknown content for the same paper the same year entitled "Ras vucadot?" (For what should we wait?) (Dzidziguri 1977: 64).

In 1907, the reaction sets in (Suny 1988: 174), and Ilia Chavchavadze is assassinated. Shanidze resurfaces in 1908-1909, writing odes to the (still living) nationalist poet Akaki Tsereteli and being disciplined for delivering an address at the Fiftieth Jubilee celebration for Tsereteli in the Kutaisi gymnasium, in which he "explained the romantic tendency of the poet as a result of the politics of tsarism in the beginning of the nineteenth century, when the hopes of the Georgian 
other literary language, is artificial: this is not a structure erected from homogeneous materials, but is compiled from different [kinds of] materials. This dialect, which was a basis for literary Old Georgian, was later complicated and enriched by words and forms brought in from various dialects" ( 9 , emphasis added). So begins his introduction to a study of Northeast Georgian mountain dialects (Pshavian, Mokhevian, Khevsurian, and Tushian), which he calls "Pkhovian" after an archaic ethnonym (11).8 Indeed, the entire preface of his short introduction to these dialects is devoted to their utility for the project of linguistic reform and revitalization of the Georgian literary language: "Today literary Georgian is very degraded: it needs revitalization. For this, however, historical and geographical knowledge of Georgian is absolutely necessary; to put it another way, the study of language already petrified on the pages of books and along with it research on living, moving language (i.e., dialects) is necessary. These two processes must proceed linked hand in hand" (10). Shanidze's opposition between an organic, "living, moving," spoken folk tradition represented by dialects and folk (presumably oral) poetic genres and a mechanical, artificial, and petrified literary language is part of the general, but often latent and of course variegated, heritage of European romanticism (Williams 1958: 36 ff.; for linguistic parallels elsewhere, see Haugen 1965 and 1969).

For Shanidze at this point in time, however, the organic tradition of dialect is clearly the hero of the story, though not always specifically in opposition to petrified literary forms. The question arises, why are specifically these dialects useful for reform, given their evident deviance from the dialects of the plains and the numerical paucity of their speakers? Why are both archaic, petrified, literary models and living, moving mountain dialects to serve as models, since presumably the lessons of these two models need not converge? Shanidze seems to anticipate the question: "The territory of these tribes [is] small and they are also small in number, they live as neighbors with each other, but in speech they differ greatly: each of them [i.e., each language] has its own distinguishing, characterizing feature. The mountain dialects are separated from the other Georgian dialects by the fact that they have preserved well the features of Old Georgian in Phonetics, Morphology, and Syntax" (Shanidze 1915: 11, emphasis added). Shanidze's views of language, particularly the role of organic, "living" dialect and spoken poetic genres in revitalizing a degraded literary language, as well as the seemingly contradictory notion of mutually reinforcing convergence of certain conservative folk dialects and certain literary monuments, have their most proximate parallels in the explicitly romantic views of his informal mentor 
various subgroups (these turn out to be the same as the two elements that fused into Georgian in 1910: Kart and Meskh respectively). The complex unity formed from diverse elements would, however, always maintain the diversity of its components in its complex nature. This "thesis of absolute permanence of linguistic matter" (Thomas 1957b: 50) is a crucial tenet of Marr's theory (from about 1916 to 1920), in which his apparently contradictory impulses toward an international unification of all existing languages and his romantic celebration of diversity is resolved: "Nothing, in itself, is destined for extinction; nothing became extinct; all languages come down to us as layers in the composition of existing contemporary languages, which are always mixed types, sometimes hybrid, but, in the majority of cases, the products of not a double but a multiple grafting" (Marr 1920: 90). Hence, his attitude toward Esperanto was initially ambivalent (Samuelian 1981: 245-46), since it represented a mechanical rather than organic synthesis: "It is clear that before us has arisen a practical problem of the working out of a universal language, an international language, which would not reach this goal mechanically, like Esperanto, but would serve psychologically as well, as an expression of the linguistic experience of all mankind, of his spiritual world" (Marr, 1923b: 176, cited in Samuelian 1981: 245).

Whereas more conventionally "Herderian" romantics (Olender 1992), or "Schleicherian" philologists (Gal and Irvine 1995: 968-969; Irvine 1995), might have posited a monadic language as an organic expression of an equally monadic and bounded folk-culture, it seems to be the individual linguistic elements that are the "monads" of Marr's system. Whereas in broadly Romantic thought in Georgia as elsewhere the genius of a language is a property of the language as a whole, for Marr the genius of a language resides in its "deathless creative elements" (Marr 1920: 106-07, cited in Thomas 1957b: 50), which seemingly retain all their crucial and distinctive properties as they are mixed and borrowed, apparently forever. The utilitarian drive for an international language can be satisfied without the psychological and expressive impoverishment of a mechanical solution like Esperanto, precisely if it uses these indestructible monads of congealed linguistic experience as its building blocks and plasters them together with the organic process of crossing and hybridization.

Akaki Shanidze, the dean of indigenized Kartvelology, also seeks to valorize the artificial, mixed nature of the Georgian language (Shanidze 1915), but the sources of his mixture are somewhat more prosaic in the context of thought of the period. Dialects (as opposed to foreign languages) are seen as repositories of a kind of raw material which can be led into the mill of the literary language to the ultimate benefit of the latter: "The Georgian literary language, like every 
Dzhavakhishvili 1956: 39, 44), when much earlier he had only claimed that Rustaveli's language was an unspecified low "folk language" with a harmonious blending of high ecclesiastical language (Marr, cited in Dzhavakhishvili 1956: 36). In contrast, Shanidze, one of the leading reformers of Georgian, found inspiration and material for language reform in the equally peripheral group of Pkhovian mountain dialects which had fascinated Georgian gentry nationalists for some time for their alleged linguistic purity and conservatism, among other things. Thus, the opposition between Marr and Shanidze continued down to their choice of "model dialect": ethnically mixed and progressive periphery (Meskh) versus ethnically pure and conservative periphery (Pkhovian).

As we have noted, Marr came to see himself as a Caucasian internationalist. Like many internationalists of the time, he reacted to the dominant Darwinist genetic motifs of comparativism and their homologous invocations in ideologies of nationalism and colonialism (cf. Hobson 1902) by simply using other concepts from the same paradigm, in particular by constantly opposing Indo-Europeanism's obsession with racial lineage with Japhetidology's heritage inherited by "crossing": "Marr's language abounded in terms such as 'crossing of languages," 'hybridization,' 'cross-breeding,' 'multiplication of languages' etc., terms borrowed from the vocabulary of Darwinism" (Thomas 1957a: 331). Marr's appropriation of the crossing metaphor from the potentialities of the organicist view of language can be seen as consistent with his long-time position as an internationalist (a position he held long before he became a "Marxist"). In this respect, Marr's position is typical of one trend of internationalist critique of nationalist and colonialist thinking of the time.

This internationalist view has direct consequences for Marr's attitude toward purism, particularly with regard to the Georgian language. Simple, unmixed languages, which in Marr's theory are also simple in the sense of having a small inventory of lexemes - he surmises that Sumerian had only "about ten words" (Marr 1923b: 42)-are weak and helpless, and he valorizes the process of mixture as not being one in which one helpless linguistic culture is subsumed within another, but both become a new unity, a unity in which the nature of both elements is preserved and which possesses a kind of hybrid vigor. "A simple language, as an infirm or helpless entity, would be invisible in the struggle of life. If, among other things, the Georgian language still exists today, its internal power flows from its diverse and rich resources; this font of qualities, however, is its complex nature completed by multiple mixtures" (Marr 1923b: 50).

He adduces proof of his theory, as usual, on a somewhat empirically counterintuitive basis, seeking to link the variation in Georgian stress patterns to the crossing of the two abstract strata, the sibilant and spirant strata and their 
distanced from Marr, just as he distanced himself increasingly from Georgian and thence all manifestations of Caucasocentrism in the later development of his theories. This linguistic opposition can be paired with his conflict with the Georgians over Persian and Armenian influences on monuments of Georgian literature. The Georgian language, along with its literary monuments and its geniuses, once the central axis of Japhetic, was still very much the centerpiece of Kartvelology and would be both the medium and object of study at the new Georgian university, whose ancillary role would be to establish and develop the apparatus of language standardization for Georgian. Thus, it is profitable to compare the attitudes of Marr and Shanidze toward the Georgian language and its more exemplary dialects.

The general opposition between Marr's internationalist valorization of mixture taking place between peoples and Shanidze's nationalist valorization of mixture taking place within peoples illuminates the basic homologous opposition between the internationalism (or Caucasian internationalism) of Japhetidology and the more typically romantic nationalist orientation of Kartvelology. Marr valorized the richness of the Georgian literary language as stemming from its complex, mixed nature. He is particularly interested in early phases of what we might now call register formation, namely, the creation of "cult languages": dialectal variation between peoples is (by crossing) revalorized as superposed (enregistered) variation ("cult languages"): "Already it is clear that an un-crossed language does not in fact exist on earth, [and] in the appearance of a cult language within a single language and in arming it with the possibility of its creation, crossing plays a great role" (Marr 1923b: 50).

Marr assumed for some time that Georgian literature and culture (like Armenian culture and literature) consisted of a mixture of two levels, a low folk or national (saero) level drawn primarily from Persian and Islamic culture, and a high ecclesiastical level drawn from Western sources (Greek and Armenian figuring prominently), although he rejected this "translationist" position by 1928 , inasmuch as talk of external creative influence and borrowing made no sense in the New Theory (Marr 1928: $11 \mathrm{ff}$.). Shanidze, as we will see, agreed on the two levels (folk and ecclesiastical) making up the Georgian literary language, but not on their foreign source. Marr championed the cultural contributions of a peripheral group of Georgians, the Meskhs (a group of Georgians from a region, Meskheti, once at the heart of Georgia, presently an Islamicized periphery), and particularly their dialect, which he assumed early on was a multiply-mixed dialect, containing admixtures not only of Svan and Armenian, but also Arabic and Persian (Dzhavakhishvili 1956: 36). This obsession grew to the extent that by 1917 Marr claimed that the epic poet Rustaveli's language was Meskhian (see 
heart of the structure of Ibero-Caucasian languages" (Chikobava 1948: v). To Marr's "methodological transcendentalism," Chikobava (1928: 107-08) opposed his own understanding of "methodological immanentism," involving the study of the "specific characteristics" and "structural peculiarities" that separate this or that (group of) language(s) from some other(s). In Chikobava's Caucasology, finding "specific characteristics" and "structural peculiarities" specific to all Caucasian languages would be the specific meaning of his methodological immanentism, and it would be axiomatic that any resemblances so found were primordial and essential, any differences accidental secondary developments (Barkava 1979: 45). All work on this subject in Tbilisi was carried out under this single scientific plan, and priority was given to relations that specifically involved Kartvelian (43). In 1933 a chair of Caucasian languages was established at T.S.U. on Chikobava's initiative, followed in 1936 by a department of Mountain Caucasian languages at the Institute of Linguistics (43). Such study may well have been motivated by an advocative tendency, similar to Marr's own early Japhetic vision, to provide a suitably interesting past where precocious promethean Caucasian metallurgists and culture-builders had once spread across most of Europe (hence the importance of Basque) and the Near East (42-45). This is the type of project that Marr was involved in even as late as 1921 , save that while the Caucasologists sought to define a methodological principle of an immanent "essence" that divided the Caucasian figure from its ground, Marr increasingly turned parochial Caucasian features into a methodologically transcendent principle that served as a ground for each new figural addition to Japhetic. Caucasology became a centripetal antithesis to the centrifugal tendencies of Japhetidology.

\section{Kartvelology: Marr and Shanidze}

As noted, the Georgian language played an axial role in Japhetic linguistics up to the founding of T.S.U., perhaps more than any other Caucasian language. However, as early as 1921 Marr's theory, while still Caucasocentric, had begun seriously to downplay the role of Georgian, originally the axis of his constructs, in favor of other Kartvelian languages (such as Mingrelian, Svan) or Georgian dialects (Meskhian), as well as other Caucasian languages. Moreover, the Georgian language, which earlier had been a "pure" representative of Japhetic, now was revealed to be a multiply-mixed language, like the Georgians themselves: "By about 1924 ... Marr's Georgians had progressed from an orphaned ethnic group to a well-connected ethnic group, to a great ethnic group, to the only ethnic group, to the very essence of human evolution" (Slezkine 1996: 840). We may surmise that on this issue his Georgian nationalist students became increasingly 
these with finality (as Dzhavakhishvili himself would attempt to do) could not rule out relations with just anyone anywhere either. Dzhavakhishvili (1937: 68) complains that the one led to the other: "N. Marr was satisfied with such documentation when proving the Japheticness of the aforesaid toponyms. Thanks to this, the Japhetic family so easily and rapidly multiplied, that the boundaries of its domain could at last contain three continents." Shanidze also complained, citing the unmotivated, and to his mind unscientific, extension beyond the boundaries of his own discipline of Kartvelology and linking resistance to the theory among specialists to this rapid extension. It is in this context that Shanidze makes his official public disavowal in 1920 of his teacher's theory:

\begin{abstract}
Niko Marr gradually expanded and changed his theory. Originally he had envisioned Georgian and Mingrelian-Chan-Svan as close relatives of the Semitic family, but soon he went further. To the Japhetic family, which originally included only Georgian, Mingrelian-Chan and Svan, he added Abkhaz, then Chechen, then Avar and other languages of Daghestan and ancient cultured languages as well, which we only know from inscriptions ... - in a word, he gave such a direction to his work that in circles of specialists, among linguists, his theory encountered distrust instead of sympathy. . . . I today here publicly must declare that the Japhetic theory of my teacher N. Marr, a theory founded on the genetic relationship of Georgian and its related languages to languages of the Semitic group, has not proven to be correct. (Shanidze 1920: 4-5)
\end{abstract}

The field of Caucasology later attempted to define itself by a specific methodology designed to include Georgian within the Caucasian languages, as well as prove more distant relations to some of the very languages that Marr had already included in Japhetic (Etruscan, Basque), always taking pains to note that Marr had not been the first to claim such a relation, 7 and always pointing out that Marr had not provided the necessary proof in these "justified" cases nor in his more "unjustified" ones (Shanidze 1920: 6; Dzhavakhishvili 1937: $63 \mathrm{ff}$.). Dzhavakhishvili, after a lengthy criticism of Marr especially on methodological grounds (1937: $63 \mathrm{ff}$.), devoted the balance of seven hundred pages to proving the relatedness of Georgian to Caucasian on the basis of a single shared morphological feature (so-called class categories), which was lacking synchronically in Georgian, but posited historically by some Caucasologists, especially those trained at the Linguistics Institute in the time of its founder, Amold Chikobava. Chikobava focused on this aspect of Dzhavakhishvili's legacy, adding to it other "specific characteristics" of Caucasian, notably the "ergative construction of the sentence-a peculiar structure that is characteristic of IberoCaucasian languages" (Barkava 1979: 44). As Chikobava puts it at the beginning of his two-volume study of this construction, "the ergative construction is the 
languages but that they were simply a stage transformation, in situ, of the already present Japhetic languages. This stage transformation was, according to Marr, called forth by a social revolution consequent upon the discovery and use of metals. (Thomas 1957a: 329-30, emphasis in the original)

The apparently facile manner in which Marr finds Japhetic elements in various languages is certainly in part due to aspects of his methodology discussed earlier (e.g., linguistic paleontology, the construct of layers). However, it should also be recognized that Marr never established (at least in print) the exact criteria for determining what constitutes a Japhetic language or language element (Dzhavakhishvili 1937: 64). Progress in Japhetidology could, therefore, come only from the theory's originator, Marr himself. Such methodological latitude rendered Marr's theories impervious to critique, and it was this that his Georgian colleagues were especially apt to criticize.

We have suggested that Marr's constant expansion of the Japhetic group was at least partially responsible for a number of changes in Japhetidological theory, leading him inexorably from a theory that was Caucasocentric in every respect (up to 1916), to one that featured a Caucasocentric methodology in a theory that was empirically internationalist in scope (up to about 1922), to an almost completely non-Caucasocentric theory soon thereafter. From the passages quoted above we can clearly see two rather dramatic reformulations in the theory which can be phrased in terms of such an immanent form of explanation. First, due to the way in which Caucasian Japhetic languages (in particular Kartvelian) served as the privileged "ground" or "axis" of Japhetic theory, the addition of each new language to the Japhetic group required altering the construct of the most fundamental Japhetic language (i.e., Georgian) so as to reveal some layer linking it with the added language. Second, Indo-European, which in 1910 Marr conceived of as a "cousin" of Japhetic (see the "Hamitic" in Figure 1), eventually came to be viewed as a kind of internal development within Japhetic triggered by an economic phenomenon (viz., the rise of metallurgy). While, following Thomas, we can see these qualitative changes as being at least partially a result of the impasse created by the extension of Japhetic from the Caucasus throughout Eurasia, it remains unclear why this expansion occurred, and why it specifically precipitated a move away from methodological Caucasocentrism.

Most of these changes in purview were viewed with dismay by the Georgian Caucasologists, although Marr's methodological deficiencies (particularly his reliance on toponyms as his sole source of data [Dzhavakhishvili 1937: 67-68]) were usually uppermost in their minds, especially when criticizing his approach to establishing the very relations that Caucasology favored (Dzhavakhishvili 1937: passim). But a lax methodology that could not establish relations such as 
constructs." Parochial categories and laws previously discovered in Caucasian materials would be universalized and applied to non-Caucasian Japhetic languages on an ad hoc basis as they were incorporated into Japhetic, often by simple identification, so that Basques are Meskhs, Iberians are Mingrelians, and so on. OfBalkan Japhetic languages, for example, Marr says revealingly only that "each of them has an opposite pure Japhetic language on the soil of the Caucasus" (1923b: 38). Marr's theories would continually use Kartvelian or Caucasian material as a point of reference, a literal ground to which any and all new languages would be referred. In order to accommodate these new members, Georgian, as the methodological axis of Japhetic par excellence, would have to undergo continual revision on the basis of what it was to include:

This theory of "layers," which Marr first elaborated in connection with the Armenian language, was generalized to the whole of Japhetic and came to be an indispensable part of Marr's methodology. As each new language was added to the Japhetic family, it [i.e., Japhetic] was found to contain a "basic layer" genetically connecting it with the newcomer. By virtue of this reasoning, Georgian, which until 1914, was considered the "purest" of all representatives of Japhetic, came to be considered, by 1922, as a hopelessly "hybrid" language with layers connecting it to a bewildering variety of other languages. (Thomas 1957a: 327-28)

After 1922 the number of languages that Marr classified as Japhetic continued to grow, leading to an impasse for his Caucasocentric methodology:

This was the state of affairs before the Japhetic family grew to unmanageable dimensions (between 1920 and 1923). Since now it encompassed much of Eurasia and since Marr was now finding Japhetic elements in Western IndoEuropean languages, the problem of migration became an acute one. The situation was a direct consequence of Marr's methodology. (Thomas 1957a: 329)

The constant expansion of the Japhetic group eventually caused Marr to reformulate his ideas concerning the position of Indo-European with respect to Japhetic and how they were related:

Inasmuch as Marr was striving to prove genetic affiliations, it would not do to have the Indo-Europeans borrowing from a Japhetic substratum and, therefore, retaining a certain portion of their language in a relatively pure state. To save the situation Marr formulated a new solution, which he read at the Academy of Sciences in November, 1923. This was the famous statement concerning "The Indo-European Languages of the Mediterranean," in which Marr asserted that the Indo-Europeans did not constitute a separate immigrating family of 
time being the history of the Orient is not sufficiently studied, and on the other hand is due to the fact that almost all of those scientists who write such works about world history and philosophy of history have specialized in studying the history of the peoples of the West" (Dzhavakhishvili 1902: 389).

But unlike Marr, Dzhavakhishvili is convinced that he is working within the received methodological framework and that these hypotheses are essentially born of ignorance. Dzhavakhishvili therefore does not generally seek to create an alternative to the received Eurocentric model, using data neglected by the Eurocentric faction. Rather, inasmuch as he seeks to correct their hypotheses using the facts of the national histories of two "oriental" peoples (Georgia and Armenia), his critique is not methodological per se, but empirical.

Thus, while Marr and Dzhavakhishvili have certain commonalities in their critique of the mistaken hypotheses and inadequate factual bases of Eurocentrism, their responses are quite different. Marr would seek a new and separate methodological ground for the new facts spurned by Eurocentric Indo-European linguistics, while Dzhavakhishvili would content himself with critiquing these mistaken hypotheses on the basis of empirical correction within the existing methodology. This methodological divide becomes increasingly clear in the period of interest to us. It would be exacerbated by Marr's growing internationalist desire to combat Indo-European hegemony by assiduously collecting all the "orphaned" non-Indo-Europeans into an empirically and methodologically united bloc, as opposed to Dzhavakhishvili's more empirically cautious nationalist critique of the hypotheses of world history.

\section{Caucasology: Prometheus Bound and Prometheus Unbound}

As has been noted, Japhetic theory underwent a vast extension of its purview from 1917 onward, so that by 1922 Marr was able to say that Japhetidology was no longer a "Caucasian science." This is in contrast to Japhetidology up to 1910, when it was essentially the same as Kartvelology, and Japhetidology of 19111916 when Japhetic became isomorphic with Caucasology. Its expansion coincides with the departure of Marr's Caucasian, specifically Georgian, colleagues and students from St. Petersburg for Tbilisi. The change in the empirical purview of Japhetic had additional theoretical consequences and it further confirmed the rift between Marr and his colleagues and students.

One of the first significant effects of the expansion was that it led Marr to propose the construct of "layers" in Japhetidological theory. Even after the empirical purview of Marr's theory was no longer limited to the Caucasus, it would remain Caucasocentric methodologically. As Thomas (1957b: 137) notes, "in many respects the Kartvelian languages remained the axis of Marr's 
and obscuring real phenomena. One of these-one can even say the main one-is the determination of the peculiarities of a race [ rasa] or race/breed [modgma] and of the soul or essence of a race. The distribution of humanity into three great races, Indo-European, Semitic, and Mongol, requires the establishment of signs of spiritual [sulieri] differentiation, which always and everywhere act upon the aforementioned three groups. (Dzhavakhishvili 1902: 390)

By means of this racial essentialization, certain peoples are effectively denied historical agency and are consigned by preordination to social stasis while others are preordained for progress.

And here, while ascertaining signs which serve to differentiate races, we are presented with an astonishing picture: a distinct boundary and enclosure of perception, of creative faculty and intellectual capacity, is established for each different race, a quality and character of religion is posited, the natural, innate inclination of people of this or that race toward being frozen at one point, toward stasis or even aspiration toward progress and social development is distinguished. There appears something similar to the predestination of the fate of peoples. (Dzhavakhishvili 1902: 390)

This racial essentialization becomes a specifically Eurocentric ideology when the opposition of racial essence is mapped onto a territorial opposition, based perhaps only on chance, yielding an Orient trapped in social stasis opposed to a dynamic colonizing Europe. "The greater part of the Indo-European race inhabit Europe, while the remaining groups of mankind dwell in the Orient; for this reason ... essentially being frozen at one point, isolation, lack of estates and classes, lack of estate- and class-struggle-in a word, psychic and social stasisis considered to be the general sign of every culture of the Orient" (Dzhavakhishvili 1902: 390).

We hardly need to point out how very similar this is to Marr's own account of the Eurocentric ideological thrust of Indo-European linguistics. Indeed, the very same hypothesis of racial essentialism and "lineage" is at issue in both historiography and linguistics, and to see this theory as an ideological plank of colonialism requires only marginally greater perspicacity (cf. Olender 1992, 1994; Gal and Irvine 1995; Irvine 1995). Whether this is an instance of Marr's influence is not at issue, indeed, it is possible that they came to this virtually identical conclusion independently, but Marr's own outbursts on the subject date from as early as 1899, at his dissertation defense (Slezkine 1996: 831, note 19).

Like Marr, Dzhavakhishvili criticizes Western historiographical hypotheses concerning the Orient partially on the basis of their empirical deficiencies. "The disregard and neglect of the Orient is on the one hand due to the fact that for the 
circle of Indo-European languages, and devoted itself to the exclusive and separate study of the Indo-European peoples. . . . It transferred to the Indo-European (Aryan) race the view of confessional theology regarding the chosen people, whose varieties inhabit mainly the European world" (Marr 1920, cited in Matthews 1949: 179-80).

Later, as part of the transition to the New Theory of Language, Marr simply subsumes European languages under Japhetic, so that they cease to exist as a methodologically or empirically separate bloc, solving once and for all the methodological impasse (Samuelian 1981: 266).

Like Marr, Ivane Dzhavakhishvili spent time in Germany (1901-1902) (Melikishvili 1979: 13) and after his return, his second lecture (26-27) was a reaction to the views of Western historiographers on the role of "Oriental" peoples in world history (Dzhavakhishvili 1902). His critique of European philosophy of history as a justification of imperialism is very similar to Marr's critique of Indo-Europeanist linguistic theory. However, his solution is ultimately quite different and rather conservative compared to Marr's wholesale revisionism. For one, he rejects in its entirety the territorial opposition between occidentalism and orientalism (ibid; see also Dzhorbenadze 1984: 81), and rather than broadly critiquing these mistaken hypotheses from a general fund of Oriental knowledge, he moves toward a nationalist critique based on the evidence of the Georgian and Armenian peoples (Dzhorbenadze 1984: 78). This move portends larger differences between Dzhavakhishvili and Marr later, namely, Marr's internationalist rejection of the European tradition of nationalistic compartmentalization of disciplines, versus Dzhavakhishvili's nationalist attempt to reproduce this compartmentalization by importing it into the Caucasus, as European forms to be filled with Caucasian content.

The philosophy of world history that Dzhavakhishvili critiques, like the philological discipline of Indo-Europeanism that Marr opposes, is Eurocentric and based on a hypothesis of naturalizing racial essentialism mapped to a territorial unity. The specific view critiqued is a hodgepodge of European ideas widespread at the time (Olender 1992: 169 note 27; Olender 1994: 21-24). For Dzhavakhishvili, the hypothesis of racial essentialism has become an ideology, in effect, being promoted from a postulate to an axiom:

It is known that in science, hypotheses, which we have never lacked, undoubtedly aid the great work of each discipline, but at the same time it often happens that the illusory orderliness and captivating clarity of the hypothesis dazzles the eyes and renders reality hazy; they become so familiar with a hypothesis, that it takes on the appearance of a theory or almost a law. . . . In the philosophy of history are found several such hypotheses, hindering work 
... In this way, the hope is that in the future the sun-truth of Japhetic linguistics will shine forth on the vault of the heaven of world science, but today . . . the nest also is demolished and has been left derelict, that nest where, over the course of 100 years, as a result of uninterrupted research, a unique school of research was revived and developed, [a school of research] with its own independent direction [whose objects of study were] the Caucasian mother-languages" (Marr 1923b: 76).

In his postscript (written in 1922 after his return from abroad) there is a more subdued tone and a different source of hope. He speaks of a "new generation" of Japhetidologists, presumably able to replace the lost "first generation" of Georgian Kartvelologists and Caucasologists. A prominent member of this second generation of Marr's students was I. I. Meshchaninov (Samuelian 1981: 247), who later, as Marr's heir, faced Dzhavakhishvili's heir, Chikobava, on the pages of Pravda. Marr's tone becomes more ominous, and not a little paranoid: "A generation, having developed skills in our field, has raised its head. But we cannot be deceived by a superficial triumph. The serpent of linguistic reaction keeps a vigil, and a Golgotha-like martyrdom awaits representatives of Japhetidology, especially the new generation" (Marr 1923b: 76-78).

Marr also refers in his autobiography (1927) to the period of the writing of this article as characterized by major changes in his relationship to the Caucasus, stated with obliqueness unusual for Marr. Having noted some early tensions with the Georgian section of the Caucasian academic circle over his affirmation of the ties of Georgian literary monuments with Persian and Armenian sources, Marr ceases direct reporting of autobiographical facts, and becomes far more oblique in his statement of events "since they are subsequently connected to now living people and institutions" (Marr 1927: 10). Presumably he is now referring, among other things, to his erstwhile Georgian students. Regarding the period 1917-1922 he says: "On account of the war and the severing of relations with the Caucasus, in time I cut short the works on Caucasian languages, and I set to work on the origin of Western languages of the Mediterranean and, in part, the unique vestige of the prehistoric languages of Europe, Basque" (Marr 1927: 12). This was when Marr earlier (1921) had described his "nest" in St. Petersburg as being "empty" and "demolished" by the scholarly secession. Clearly, a significant part of his change in orientation was not due merely to the practical difficulties involved in travel to the Caucasus (though these were of course great); his alienation also stems from his abandonment by the first generation of Georgian students. 
The empirical move away from the Caucasus is combined with a methodological shift: Marr makes clear in 1921 that his new interest in Basque will not involve the same "simple relation" (i.e., a genetic one) favored by the dissident Caucasologists: "Now it no longer suffices for us to say that the Basque language belongs to the Japhetic family of languages and, among other things, is related to the Caucasian Japhetic languages, for example Georgian, Mingrelian, Svan, Abkhaz, Batsbi (Tsova-Tush), Avar, and others" (Marr 1923b: 32).

In his autobiography he notes that his rejection of such a simple relation coincides with a move away from a Caucasocentric theory, a recapitulation of the form of Indo-European linguistics (proto-families) with a new content. He is explicitly renouncing the methodological principles of Caucasology as purveyed by Dzhavakhishvili: "I determined a series of signs of kinship between Basque and the dead Etruscan language and the Japhetic languages of the Caucasus, but I rejected the thought which had suddenly sprung up to connect the origin of the Japhetic languages with a certain Basque language, and thereby make the Caucasus the proto-family of all the ancient languages" (Marr 1927: 12).

Thus at a time (1922) when Marr began to characterize his new phase of Japhetidological research as being no longer a Caucasian science, a specifically Caucasian science, Caucasology, whose pioneers were his first generation of students and colleagues, had arisen in Georgia. Marr increasingly opposed his Caucasian internationalist Japhetic theory to the Nationalist Caucasology of his dissident students, to the detriment of the Caucasocentrism of Japhetic. However, the dissident specialty of Caucasology had become institutionalized in Georgia in the meantime, even as Marrism held sway over the remainder of the Soviet Union, so that even on the eve of the Pravda discussion on linguistics, Georgian resistance to Marr's theory remained the one black spot in the triumphant litanies to the success of Marrism held on his eighty-fifth anniversary: "Unfortunately, things are different in the institutes of the Georgian Academy of Science where Marr's teaching is criticized and old, definitely discarded methods used" (Spirkin 1949: 4). Ironically, and probably not at all coincidentally, a second generation Caucasologist, Amold Chikobava (who had been singled out by name for criticism by the Marrists in 1949 [ibid, 6] and had confronted Marr in person at a lecture in Tbilisi in 1930 [Dzhibladze 1988]), was selected by Stalin to deliver the coup de grâce to Japhetidology (Chikobava 1985). In recent years Marr has been rehabilitated in Georgia as an (errant) contributor to the foundation of the very disciplines - Caucasology, Kartvelology, Rustavelology-on which he differed so strongly from his Georgian students (Dzidziguri 1985, 1988). Even more striking has been the translation of this rehabilitation among the Georgian intelligentsia into providing part of the conceptual ballast for the political program 
or ideology of the late ex-president of Georgia, Zviad Gamsakhurdia.14 The final irony is that Marr, an internationalist, has entered Georgian history as a figure of national(ist) importance. 


\section{References}

Baggioni, Daniel. 1977. "Contribution à l'histoire de l'influence de la 'Nouvelle Théorie du langage' en France." Langages 46:90-117.

Barkava, M. [Bark'ava]. 1979. Arnold chikobava: biobibliograpia. Tbilisi: Mecniereba.

Bauman, Zygmunt. 1987. "Intellectuals in East-Central Europe: Continuity and change." Eastern European Politics and Societies 1.2:162-86.

Calvet, Louis-Jean. 1974. Linguistique et Colonialisme. Paris: Payot.

Charachidze, G 1959. "Contemporary Soviet views on 'Caucasology'." Caucasian Review 8:70-78.

Chikobava, Arnold [Arnold Chikobava]. 1928. Mart'ivi c'inadadebis p'roblema kartulshi [The problem of the simple sentence in Georgian]. Reprint 1968. Tbilisi: Mecniereba.

1938. Ch'anur-megrul-kartuli shedarebiti leksik'oni [Chan-MingrelianGeorgian comparative dictionary]. Tbilisi: SSRK mecnierebata ak'ademiis sakartvelos pilialis gamomcemloba.

1948. Ergat 'iuli k'onst'rukciisp'roblema iberiul-k'avk'asiur enebshi I [The problem of the ergative construction in Ibero-Caucasian languages I]. Tbilisi: Sakartvelos SSR mecnierebata ak'ademiis gamomcemloba.

1950. "On certain problems of Soviet linguistics." Translated in Murra et al., 1951, 9-19.

. 1961. Ergat 'iuli k'onst 'rukciis p'roblema iberiul-k'avk'asiur enebshi II [The problem of the ergative construction in Ibero-Caucasian languages II]. Tbilisi: Sakartvelos SSR mecnierebata ak'ademiis gamomcemloba.

- 1985. "When and how it happened." Iberiul-k'avk'asiuri enatmecnierebis c'elic'deuli 12:39-52.

Clark, Katerina. 1995. Petersburg, Crucible of Cultural Revolution. Cambridge, Mass.: Harvard University Press.

Confino, Michael. 1972. "On intellectuals and intellectual traditions in eighteenth- and nineteenth-century Russia." Daedalus 101:117-49.

Dzhavakhishvili, Ivane [Ivane Dzhavaxishvili]. 1902. "Aghmosavletis xalxta ist'oria da sakartvelos da somxetis ist'oriis monacemebi" [The history of Oriental peoples and the facts of the history of Georgia and Armenia]. Reprint 1960. In Kartuli eris ist'oria, $t$ '. 1 [History of the Georgian People, vol. 1], damt'eba 1 [supplement 1], 389-99. 
1913. "Kartuli leksik'onis shesaxeb" [Concerning the Georgian dictionary]. Reprint 1956. In Kartuli enisa da mc'erlobis ist'oriis sak'itxebi [Questions on the history of Georgian language and literature], 156-62. Tbilisi: Sakartvelos SSR mecnierebata ak'ademiis gamomcemloba.

1917. "Kartuli universit'et'is daarsebis aucileblobis shesaxeb" [On the necessity of founding a Georgian university]. TSU Shromebi 28B, 1-11. Tbilisi: Tbilisi State University.

1937. Kartuli da k'avk'asiuri enebis tavdap 'irveli buneba da natesaoba [The original nature and relationship of the Georgian and Caucasian languages]. Tbilisi: SSRK mecnierebta ak'ademiis sakartvelos pilialis gamomcemloba.

1937b. "Chveni amocanebi enatmecierebisa da k'ult'uris ist'oriis speroshi" [Our tasks in the sphere of linguistics and the history of culture]. Reprint 1956. In Kartuli enisa da mc 'erlobis ist 'oriis sak'itxebi [Questions on the history of Georgian language and literature], 89-96. Tbilisi: Sakartvelos SSR mecnierebata ak'ademiis gamomcemloba.

- 1956. "Vepxist'q'aosani" [The knight in the tiger's skin]. In Kartuli enisa da mc'erlobis ist'oriis sak'itxebi [Questions on the history of Georgian language and literature], 31-47. Tbilisi: Sakartvelos SSR mecnierebata ak'ademiis gamomcemloba.

Dzhibladze, G. [G. Dzhibladze]. 1988. "Nik'o maridan nik'o maramde (shesavali sit'q'va)" [After Marr and before Marr (introduction)]. In Dzidziguri, ed. 1988, 5-14.

Dzhorbenadze, Sergo [Sergo Dzhorbenadze]. 1984. Cxovreba da ghvac 'li ivane dzhavaxishvilisa [The life and works of Ivane Dzhavakhishvili]. Tbilisi: Tbilisis universit'et'is gamomcemloba.

Dzidziguri, Shota [Shota Dzidziguri]. 1969. The Georgian Language (Short Review). Tbilisi: Tbilisi University Press.

- 1977. Ak'ak'i shanidze, biobibliograpia [Akaki Shanidze, Biobibliography]. Tbilisi: Mecniereba.

-. 1985. Nik'o mari kartuli k'ult'uris mk'vlevari [Niko Marr, researcher of Georgian culture]. Tbilisi: Mecniereba. sakartvelo."

ed. 1987. Ak'ak'i Shanidze. Tbilisi: Gamomcemloba “sabch'ota

ed. 1988. Ak'ademik'osi nik'o mari-120 [Academician Niko Marr120]. Tbilisi: Mecniereba.

Eco, Umberto. 1997. The Search for the Perfect Language. Translated by James Fentress. Oxford: Blackwell.

Ellis, J., and R. W. Davies. 1951. "The crisis in Soviet linguistics." Soviet Studies 2:209-64. 
Enwall, Joakim. 1992. "Some remarks on the language debate in the Mingrelian newspaper 'Qazaqishi Gazeti'." In Caucasian Perspectives, edited by B. G Hewitt, 278-84. Munich: LINCOM EUROPA.

Gal, Susan, and Judith Irvine. 1995. "The boundaries of languages and disciplines: How ideologies construct difference." Social Research 62, 4:9671001.

Gal, Susan, and Kathryn Woolard. 1995. "Constructing languages and publics: authority and representation." Pragmatics 5, 2:129-38.

Gamkrelidze, Thomas. 1966. "A typology of Common Kartvelian." Language 42:69-82.

Gamsakhurdia, Zviad. 1990. The Spiritual Mission of Georgia. Reprint 1991. Tbilisi: Ganatleba.

Haugen, Einar. 1965. "Construction and reconstruction in language planning: Ivar Aasen's Grammar." Reprint 1972. The Ecology of Language, 191-214. Stanford, Calif.: Stanford University Press.

- 1969. "Language planning, theory and practice." Reprint 1972. The Ecology of Language, 287-98. Stanford, Calif.: Stanford University Press.

Herzfeld, Michael. 1987. Anthropology Through the Looking Glass. Cambridge: Cambridge University Press.

Hewitt, B. G 1990. "Aspects of language planning in Georgia (Georgian and Abkhaz)." In Language Planning in the Soviet Union, edited by M. Kirkwood. New York: St. Martin's.

1992. "Languages in contact in N. W. Georgia: fact or fiction?" In Caucasian Perspectives, 244-58. Munich: LINCOM EUROPA.

1995. "Yet a third consideration of Völker, Sprachen un Kulturen des südlichen Kaukasus." Central Asian Survey 14, 2:285-310.

Hobson, J. A. 1902. Imperialism: A Study. New York: James Pott.

Hofer, Tamás. 1980. "The creation of ethnic symbols from the elements of peasant culture." In Ethnic Diversity and Conflict in Eastern Europe, edited by Peter F. Sugar, 101-45. Oxford: ABC-Clio.

Irvine, J. 1995. "The family romance of colonial linguistics: Gender and family in nineteenth-century representations of African languages." Pragmatics 5:139-53.

Itonishvili. 1990. Kartveli xalxis etnost 'rukt'ura mrude sark'eshi [The Georgian people's ethno-structure in a distorting mirror]. Tbilisi: Mecniereba

Jones, Stephen. 1996. "Georgian-Armenian relations in 1918 to 1920 and 1991 to 1994: A comparison." In Suny, ed. 1996, 441-60.

Kagarlitsky, B. 1988. The Thinking Reed: Intellectuals and the Soviet State from 1917 to the Present. London: Verso. 
Lashauri, Mindia. 1955. "The State of Historical Science in the Georgian SSR" Caucasian Review 1:93-99. Munich: Institute for the Study of the USSR.

Layton, Susan. 1986. "The creation of an imaginative Caucasian geography." Slavic Review 45:470-85.

- 1994. Russian Literature and Empire: conquest of the Caucasus from Pushkin to Tolstoy. Cambridge: Cambridge University Press.

Lomtatidze, K. [K. Lomtatidze]. 1968. "I. dzhavaxishvili da kartulisa da mtis iberiul-k'avk'asiuri enebis ist'oriul-genet'uri urtiertobis p'roblema" [I. Dzhavakhishvili and the problem of the historical-genetic relationship of the Georgian and Ibero-Caucasian (languages)]. In Iberiul-k'avk'asiuri enatmecniereba 16:263-72.

Manning, Clarence Augustus. 1931. "Japhetidology." Language 7:14346.

Marcellesi, Jean-Baptiste. 1977. "A propos du marrisme: 'ni cet excès d'honneur, ni cette indignité'." Langages 46:3-23.

Marr, Nikolaj [Nik'o Mari]. 1888. "Buneba da tviseba kartulis enisa (mcire shenishvna)" [The nature and character of the Georgian language (short note)]. Reprint 1926. In Marr 1926a, 1-4.

1908. "Predvaritel'noe soobshchenie o rodstve gruzinskogo jazyka s semiticheskimi." Reprint 1926. In Marr 1926a, 8-30.

- 1910. Chanskago (lazskago) jazyka. In Materialy po jafeticheskomu jazykoznaniju, vol. 2. St. Petersburg: Nauk.

1918. "O Kavkazskom Universitete v Tiflise." Izvestija rossijskoj akademii nauk. 6th ser. 12:1496-516.

-. 1920. Jafeticheskij Kavkaz $i$ tretij ètnicheskij èlement $v$ sozidanii sredizemnomorskoj kul 'tury. In Materialy po jafeticheskomu jazykoznaniju, vol. 11. St. Petersburg: Nauk.

1923a. Der japhetische Kaukasus. Berlin: W. Kohlhammer Verlag, 1923. (Translation of Marr 1920.)

1923b. Rit cxovrobs iapet 'uri enatmecniereba? [By what means does Japhetic linguistics live?]. Petrograd: Saxalxo sakmeta k'omisariat'i, p'et' rogradis aghmosavletur cocxal enat inst'it'ut' $i 2$. Originally presented as a lecture in Berlin in 1921. Published in 1922 as a pamphlet by the Institute of Modern Oriental Languages in Petrograd. While the original version was written in Georgian (with Georgian on one side and Marr's system of transcription on the facing page), it was eventually translated into Russian: Chëm zhivöt jafeticheskoe jazykoznanija. This translation is found in Marr, Izbrannye Raboty, vol. 1, 158-84. Leningrad: Izdatel'stvo Gaimk, 1933.

—. 1926a. Po ètapam razvitija jafeticheskoi teorii. Moscow and Leningrad. 
—. 1926b. "O proisxozhdenii jazyka." In Marr 1926a, 286-335.

—. 1927. "Avtobiografija." Ogonëk 27, July 3. Reprint 1933. In Izbrannye Raboty, vol. 1, 6-13. Leningrad: Izdatel'stvo Gaimk.

- 1928. "La language géorgienne." Revue de l'Orient Chrétien 26:1-19.

Marr, Nikolaj, and Maurice Brière. 1931. La langue géorgienne. Paris: Firmin-Didot.

Matthews, W. K. 1949. "The Japhetic Theory." American Slavic and East European Review 8:172-92.

-. 1950. "The Soviet contribution to linguistic thought." Archivum Linguisticum 2:1-23, 97-121.

Meillet, A. 1928. Review of Marr, Po ètapam razvitija jafeticheskoj teorij. BLSP 28:226-28.

Melikishvili, G. [G. Melikishvili]. 1979. “Ak'ademik'osi ivane dzhavaxishvili (1876-1940)" [Academician Ivane Dzhavakhishvili]. In Ivane dzhavaxivili: txzulebani [Ivane Dzhavakhishvili: Collected works], edited by M. Inasaridze, 1:10-30. Tbilisi: Tbilisis universit'et'is gamomcemloba.

Murra, John V., Robert M. Hankin, Fred Holling, trans. 1951. The Soviet Linguistic Controversy. New York: King's Crown Press.

Olender, Maurice. 1992. The Languages of Paradise: Race, Religion, and Philology in the Nineteenth Century. Translated by Arthur Goldhammer. Cambridge, Mass.: Harvard University Press.

1994. "Europe, or how to escape Babel." History and Theory 33:5-25.

Pshavela, Vazha [Vazha Pshavela]. 1888. "Mcire shenishvna: p'asuxad bn. p. marianashvilisa" [Brief note: In response to Mr. P. Marianashvili]. In Txzulebani [Collected works], 632-35. Tbilisi: Gamomcemloba "Sabch'ota sakartvelo," 1986.

Rayfield, Donald. 1994. The Literature of Georgia: A History. Oxford: Clarendon Press.

Rhinelander, L. H. 1996. "Viceroy Vorontsov's adminsitration of the Caucasus." In Suny, ed. 1996, 87-104.

Rubenstein, Herbert. 1951. "The recent conflict in Soviet linguistics." Language 27:281-87.

Said, Edward. 1978. Orientalism. New York: Vintage Books.

Saiubileo [Jubilee]. 1968. In Dzveli kartuli enis k'atedris shromebi [Works of the Department of Old Georgian], vol. 11. Tbilisi: Tbilisi State University.

Samuelian, Thomas. 1981. The Search for a Marxist Linguistics in the Soviet Union, 1917-1950. Ph.D. diss., University of Pensylvania.

Saroyan, M. 1996. "Beyond the nation-state: culture and ethnic politics in Soviet Transcaucasia.” In Suny, ed. 1996, 401-26. 
Shanidze, Akaki [Ak'ak'i Shanidze]. 1915. Kartuli k'iloebi mtashi [Georgian mountain dialects]. Reprint 1984. In Txzulebani [Collected works], vol. 1. Tbilisi: Mecniereba.

1920a. "Subiekt'uri p'repiksi meore p'irisa da obiekt'uri p'repiksi mesame p'irisa kartul zmnebshi" [The second person subject prefix and third person object prefix in Georgian verbs]. Reprint 1957. In Kartuli enis st 'rukt 'urisa da ist'oriis sak'itxebi [Questions of the structure and history of Georgian] 1:111-263. Tbilisi: Stalin Tbilisi State University Publishers. $1-6$.

—. 1920b. "Shesavali sit'q'va" [Introduction]. Reprint 1968. In Saiubileo,

_. 1980. Kartuli enis gramat 'ik'is sapudzvlebi [Fundamentals of Georgian grammar]. In Txzulebani [Collected works], vol. 3. Tbilisi: Georgian SSR Scientific Academy, Tbilisi State University.

1988. "Nik'o mari" [Niko Marr]. In Dzidziguri, ed. 1988, 15-19.

Shnirelman, Victor. 1995. "From internationalism to nationalism: forgotten pages of Soviet archaeology in the 1930s and 1940s." In Nationalism, Politics, and the Practice of Archeology, 120-38, edited by Philip Kohl and Clare Fawcett. Cambridge: Cambridge University Press.

Slezkine, Y. 1996. "N. Ia. Marr and the national origins of Soviet ethnogenetics." Slavic Review 55, 4:826-62.

- 1994. "The USSR as a communal apartment, or how a socialist state promoted ethnic particularism." Reprint 1996. In Becoming National, 203-38, edited by G. Eley and R. G. Suny. London: Oxford.

Smith, Michael. 1991. Soviet Language Frontiers: The Structural Method in Early Language Reforms 1917-1937. Ph.D. diss., Georgetown University.

Songhulashvili, Avtandil. 2001. "Tbilisis universit'et'is roli sakartvelos int'eligenciis pormirebashi (1918-1921 c'c')" [The role of Tbilisi University in the formation of the intelligentsia of Georgia (1918-1921)]. In Nark'vevebi sakartvelos ucxlesi ist 'oriidan [Essays from the most recent history of Georgia], 3-20, edited by Avtandil Songhulashvili. Tbilisi: Mecniereba.

Spirkin, A. G 1949. "Scientific session devoted to Marr Anniversary." Translated in Murra et al., 1951, 1-9.

Suny, Ronald. 1988. The Making of the Georgian Nation. Bloomington: Indiana University Press.

1993. The Revenge of the Past: Nationalism, Revolution and the Collapse of the Soviet Union. Stanford, Calif.: Stanford University Press.

ed. 1996. Transcaucasia, Nationalism, and Social Change. Rev. ed. Ann Arbor: University of Michigan Press. 

1996, 109-40.

Thomas, Lawrence L. 1957a. "Some Notes on the Marr School." American Slavic and East European Review 16:323-48.

1957b. The Linguistic Theories of N. Ja. Marr. Berkeley and Los Angeles: University of California Press.

Trubetzkoy, N. S. 1924. Principles of Phonology. Translated by Christine A. M. Baltaxe. Berkeley and Los Angeles: University of California Press, 1969.

Verdery, K. 1991. National Ideology under Socialism: Identity and Cultural Politics in Ceausescu's Romania. Berkeley and Los Angeles: University of California Press.

Williams, R. 1958. Culture and Society: 1780-1950. New York: Columbia University Press.

Yaguello, Marina. 1984. Lunatic Lovers of Language. Translated by Catherine Slater. London: Athlone, 1991. 


\section{Notes}

A preliminary version of this paper was presented at the Eighth Biennial Conference on the Cultures of Caucasia, University of Chicago, May 10, 1997. We wish to thank the participants in that conference for their suggestions, comments, and questions. We also wish to thank B. George Hewitt, Stephanie Platz, David Testen, Kevin Tuite, and Elissa Watson for their comments on various drafts. Special thanks are due to Howard Aronson not only for his extensive written comments, but also for having sparked our interest in the work of Marr. The final draft also benefited from the comments and suggestions of two anonymous reviewers. Any errors or inaccuracies are the responsibility of the present authors.

1. For example: amorphous > agglutinative > inflectional (Matthews 1949: 184; Ellis and Davies 1951: 216).

2. For example: primitive communism > division of labor $>$ class society (Ellis and Davies 1951: 216). Rubenstein (1951: 284) offers a more reticulated scheme: "primitive communal > slave-holding $>$ feudal $>$ capitalist $>$ socialist $>$ communist."

3. An independent reviewer suggests that perhaps this assessment of Marr's lack of knowledge of Marxism is too strong, pointing out that Marr was strongly affected by witnessing the events of the 1905 revolution in Guria, as were many Georgian social democrats (Suny 1988: 166). We disagree that this movement was necessarily "Marxist," or that witnessing it would lead inexorably to familiarization with Marxist ideas; Shanidze, for example, seems to have been led to anarchism by the same stimulus. We must also distinguish between self-conscious and systematic knowledge of Marxism (of whatever variety) and any of the vernacular. varieties of patchy familiarity common among intellectuals. Certainly many Marxist ideas were in the air, and Marr would have been familiar with these and many other revolutionary ideas from well before 1905 , but this does not imply any specific allegiance to or detailed knowledge of "Marxism." Indeed, judging from his later putative Marxism, he never really assimilated any form of Marxism as a system. We must therefore distinguish between self-conscious appropriation of specifically Marxist ideas (which happened later) versus a general conversance with ideas that were part of his social milieu as an intellectual (from before the 1905 revolution, possibly).

4. One of the most recent discussions is Eco (1997: 114-15), specifically citing Marr.

5. This particular club could be used with equal facility to bludgeon the nationalist "lineage" advanced by his Georgian students.

6. "My thesis is that the essential aspects of modern Orientalist theory and praxis (from which present-day Orientalism derives) can be understood . . . as a set of structures inherited from the past, secularized, redisposed, and re-formed by such disciplines as philology, which in turn were naturalized, modernized and laicized substitutes for (or versions of) Christian supernaturalism" (Said 1978: 122).

7. Friedrich Müller's pronouncements of 1864 are often cited in this regard (Dzidziguri 1969: 21-22; Barkava 1979: 42) Dzhavakhishvili 1937 gives a lengthy intellectual genealogy.

8. In 1915, Pkhovian (pxouri) is the name that Shanidze gives to these dialects, after an archaic ethnonym, and his list in this article includes Khevsurian, Pshavian, Tushian and 
Mokhevian, but excludes Mtiulian (and Gudamaqrian), though these dialects are included in the scope of the article. By 1957, Shanidze's Pkhovian would exclude Pshavian as well (Dzidziguri 1987: 57), which now forms a separate dialect group with Mtiuletian. By contrast, for his predecessor, Vazha Pshavela, the term is simply an archaic form of modern "Pshav," the "central" Pkhovian dialect.

9. Cf. Haugen $(1965,1969)$.

10. Marr's contribution to the Meskhian question seems like an attempt to suture the opposed views of Meskheti he inherited from the nineteenth-century Georgian press. Meskheti was identified by Georgian intelligentsia as the center of an earlier flowering of Georgian culture soon after the Russo-Ottoman war of 1877, but was discovered at the same time to be in some sense no longer Georgian, having been "Tatarized." In 1888 a minor debate erupted in the pages of Iveria when P. Marianishvili (in an article entitled "National Language and Local Dialect," appearing in volume 166 of Iveria for 1888) claimed that golden-age Meskheti, and not Kartli, had been the place where the Georgian literary language had been born. Since he also had some critical things to say about the use of local dialect (particularly Pshavian) in literature, his assertions drew a certain amount of criticism and discussion in subsequent issues. This debate on the significance of the Meskhian dialect to Georgian national culture occurred at the same time as Marr's first publication in the same newspaper. By identifying these opposed poles-the golden age when Meskheti was Georgia's cultural center and the fallen present represented by the Islamicized Meskhians of today-in the figure of Rustaveli, Marr overcame this disjuncture within the old and the new Meskheti.

11. The month and date are from Lashauri (1955: 94).

12. The commission's findings clearly made the proposed Georgian university a private, subordinate adjunct to a public state university of the Caucasus, presumably at Marr's initiative and behest. To this end, the commission's finding (from the meeting of 28 September 1917) specified that (1) the private Georgian university would not have the right to grant doctoral degrees, and (2) it would not have the right to exempt its students from military service (with the war still in progress, this would effectively deprive it of any students at all). The same commission, meeting on 19 October 1917, on its own initiative investigated the possibility of setting up a public Caucasian university in Tbilisi, to which the private Georgian university would be a lesser partner (Dzhorbenadze 1984: 209-10).

13. Kevin Tuite (personal communication) has pointed out that Chikobava has employed this word in the Soviet usage (viz., drevnekhettskij) to designate Hattic (proto-Hittite), not Hittite itself.

14. For instance Gamsakhurdia (1991: 24) is rife with appeals to Marr, who emerges as a post-communist hero precisely because Stalin finally denounced him. Like the others who attempt to rehabilitate Marr, Gamsakhurdia identifies Japhetic with Caucasian in the broadest sense, and treats all these terms, over the differentiation of which so much ink and not a little blood had been spilt in the past, as being merely terminological variants. 